\title{
Review \\ Phytochemicals and Biological Activities of Barleria (Acanthaceae)
}

\author{
Serisha Gangaram ${ }^{1}\left(\mathbb{D}\right.$, Yougasphree Naidoo ${ }^{1}$, Yaser Hassan Dewir ${ }^{2,3, * \mathbb{D}}$ and Salah El-Hendawy ${ }^{2,4}{ }^{(\mathbb{D}}$ \\ 1 School of Life Sciences, Westville Campus, University of KwaZulu-Natal, Private Bag X54001, \\ Durban 4000, South Africa; serishagangaram@yahoo.com (S.G.); naidooy1@ukzn.ac.za (Y.N.) \\ 2 Plant Production Department, College of Food and Agriculture Sciences, King Saud University, P.O. Box 2460, \\ Riyadh 11451, Saudi Arabia; mosalah@ksu.edu.sa \\ 3 Department of Horticulture, Faculty of Agriculture, Kafrelsheikh University, Kafr El-Sheikh 33516, Egypt \\ 4 Department of Agronomy, Faculty of Agriculture, Suez Canal University, Ismailia 41522, Egypt \\ * Correspondence: author: ydewir@ksu.edu.sa
}

check for updates

Citation: Gangaram, S.; Naidoo, Y.; Dewir, Y.H.; El-Hendawy, S.

Phytochemicals and Biological

Activities of Barleria (Acanthaceae).

Plants 2022, 11, 82. https://doi.org/ $10.3390 /$ plants 11010082

Academic Editors: Ahmed

A. Hussein and Sebastian Granica

Received: 27 October 2021

Accepted: 22 December 2021

Published: 28 December 2021

Publisher's Note: MDPI stays neutral with regard to jurisdictional claims in published maps and institutional affiliations.

Copyright: (c) 2021 by the authors. Licensee MDPI, Basel, Switzerland. This article is an open access article distributed under the terms and conditions of the Creative Commons Attribution (CC BY) license (https:// creativecommons.org/licenses/by/ $4.0 /)$.

\begin{abstract}
Plant species belonging to the family Acanthaceae are globally known to possess various medicinal properties and have cultural and economic importance in both traditional medicine and horticulture. They are important to both animals and humans and are used as food or for ornamental purposes worldwide. Barleria is the third largest genus in the family Acanthaceae. A few of the highly important and reported species of Barleria include B. prionitis, B. cristata, B. grandiflora, and B. lupulina. The flowers, leaves, stems, roots, and seed extracts of plants belonging to this genus are rich in bioactive compounds and have exhibited significant medicinal potential for the treatment of various ailments and infections. Evidence derived from several studies has demonstrated the antioxidant, antibacterial, antifungal, anti-inflammatory, anticancer, antidiabetic, antiulcer, hepatoprotective, analgesic, antiamoebic, antihelminthic, antiarthritic, antihypertensive, antiviral properties and toxicity of extracts, in addition inhibition of acetylcholinesterase activity and biosynthesis of nanoparticles, of the plant and seed extracts of species belonging to Barleria. Studies have reported that bioactive compounds such as flavonoids, quinones, iridoids, phenylethanoid glycosides, the immunostimulant protein "Sankaranin", and antibiotics isolated from Barleria species are resposnsible for the above biological activities. Traditionally, the genus Barleria has significant medicinal potential; however, there is a scarcity of information on various species that are yet to be evaluated. This review provides a comprehensive report on existing literature, concerning the phytochemistry and biological activities of the genus Barleria.
\end{abstract}

Keywords: Acanthaceae; Barleria; bioactive compounds; medicine

\section{Introduction}

Traditional medicine is an ancient practice which is nearly as old as the existence of mankind. This declaration is backed by evidence obtained from studies of the older civilizations of human settlements where paleontologists discovered bunches of medicinal herbs among the fossilized remains of Neanderthal ancestors [1]. Previously, man depended solely on higher plants for medicine, and this dependence is still apparent in the present era [2-5]. Traditional preparations of plants continue to offer mankind novel remedies. Plants are rich in a diversity of secondary metabolites such as alkaloids, flavonoids, terpenoids and tannins which have been found to have antimicrobial properties [6-9]. Plant extracts have treated various infectious diseases throughout the history of mankind [10-12] by means of herbal preparations. These include concoctions, decoctions, infusions and teas [13]. Ancient texts of the Vedas and the Bible have described some of these traditional practices, using traditional herbs $[14,15]$. A great deal of conventional medicine have also originated from plant extracts, with some of the effective drugs being plant-based, such as aspirin from the bark of the willow tree [16]. 
Medicines manufactured by pharmaceutical companies are largely synthetic [17]. The fear for adverse side-effects and toxicity, has brought about further scientific investigations on the potential usage of medicinal plants [18]. The increasing use of medicinal plants in various cultures has prompted scientific studies into natural products. These studies [14,15] are aimed at evaluating whether various cultures traditional practices in using natural products are supported with evidence on their pharmacological effects or if their use is simply based on folklore [19]. Due to the growing interest in the use of traditional medicine, it is essential to meet some of the concerning challenges such as: the overall lack of research, evidence of safety, efficiency and high quality of natural products, lack of patenting rights of traditional medicines and, the need to maximize and integrate natural products as possible sources of remedies in primary health care $[20,21]$. Various techniques have been used in extracting compounds from medicinal plants for the production of drugs. These include the isolation of compounds from plants and other natural sources, molecular modelling, synthetic and combinatorial chemistry [22]. The significance of plants as one of the natural sources of medicines can never be over-emphasized, as approximately $25 \%$ of prescribed drugs worldwide originate from plants [23]. Fifty five categorized human diseases such as cancer, parasitic and microbial infections were researched by Newman et al. [24]. It was found that $87 \%$ of medications used for treatment were derived from natural products extracted from plants. Fabricant and Farnsworth [25] showed that 122 bioactive compounds from approximately 94 plant species were consumed as clinical drugs. Knowledge of the use of plants in traditional medicine is beneficial to healers and the pharmaceutical industry. Also, the validation of the ethnomedicinal traditional practiceusing new scientific approaches can benefit a large number of individuals [26]. There is a growing need in linking the phytochemical compounds of a medicinal plant with its pharmacological activity [27]. Many plant species of Acanthaceae possess great therapeutic potential, whilst some are unexplored to-date [28]. Plant species of this family play an important role to both man and animals as they are used for food, medicine or as ornamentals [29-31] and contain many essential secondary metabolites, some include, alkaloids, terpenoids, tannins, quinones and flavonoids [28]. Several plant species are being utilized for their ethnomedicinal properties based on their phytocompounds they acquire, with Barleria (Acanthaceae) being one of such genera. The genus Barleria belongs to the Acanthaceae family [32] (Figure 1). The maximum representation of Barleria is in Africa where the diversity exists in two centers, one in tropical east Africa (approximately 80 species) and the other in southern Africa (approximately 70 species) [33]. The name Barleria was provided by a French botanist and Dominican monk, Jacques Barrelier (1606-1673), who dedicated his spare time to botany [34]. Barleria is the third largest genus in the family Acanthaceae after Justicia and Ruellia [35-37], and it is the most species-rich genus in Barlerieae [38]. This genus includes approximately 300 species of shrubs and herbs that are distributed in the subtropical and tropical regions of the world [39-43]. The members of this genus have originated from the Far East of Japan, through southern Asia, Arabia, India, Kenya, Tanzania, Angola, Democratic Republic of the Congo, Namibia, Botswana, Mozambique, southern Africa, and Madagascar to as far West of Central America and Mexico [33,42]. Barleria is predominantly an "Old World genus" (a term used in the West to refer to Africa, Asia, and Europe), with its maximum species diversity being present in east tropical Africa followed by South Africa [33]. The distribution of Barleria throughout Africa is illustrated in Figure 2. In southern Africa, there are 70 species of Barleria of which approximately $65 \%$ are endemic to the region $[43,44]$. 


\begin{tabular}{|cc|}
\hline Kingdom & Plantae \\
Sub-kingdom & Tracheobionta \\
Division & Magnoliophyta \\
Class & Magnoliopsida \\
Sub-class & Asteridae \\
Order & Scrophulariales \\
Family & Acanthaceae \\
Genus & Barleria \\
\hline
\end{tabular}

Figure 1. Taxonomic hierarchy of the genus Barleria.

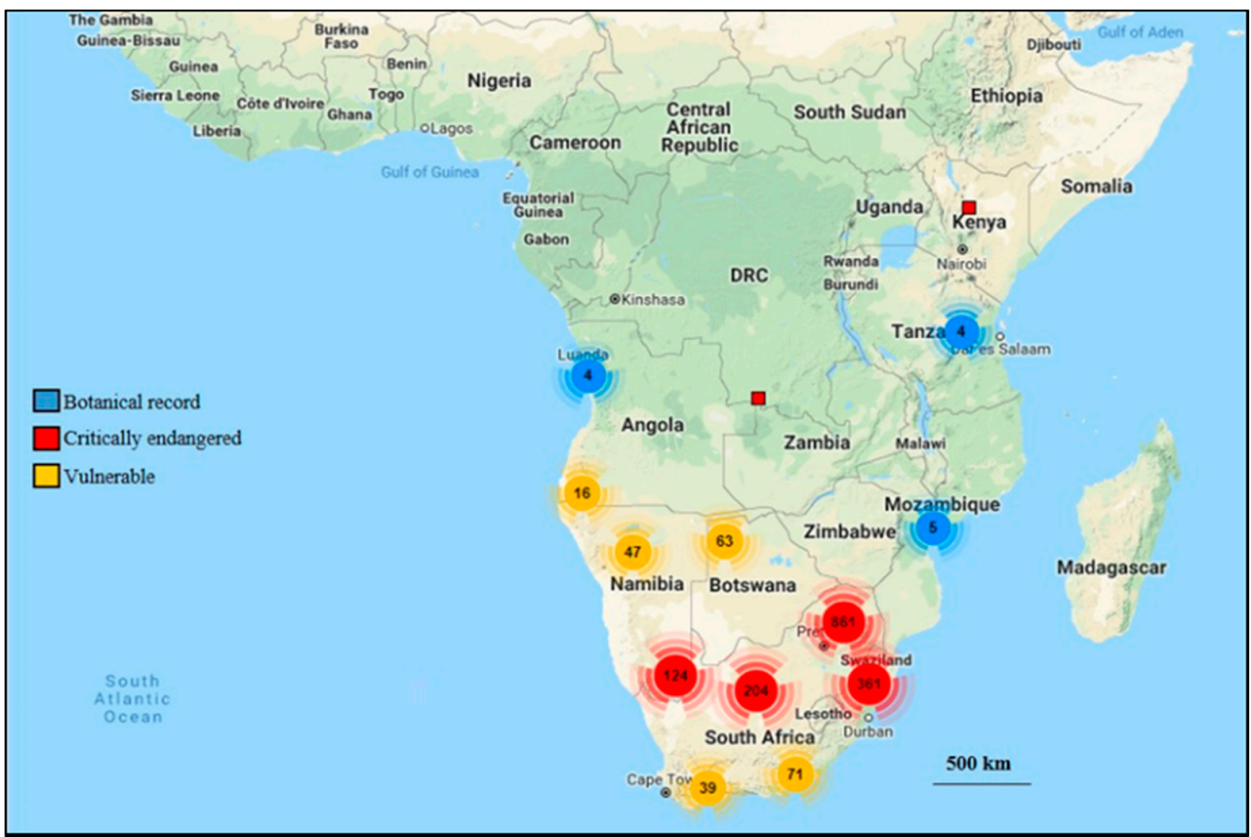

Figure 2. Distribution map of species of Barleria in Africa. Adapted from SANBI BRAHMS online (http:/ / newposa.sanbi.org/sanbi/Explore) (accessed on 14 June 2021).

Barleria can be easily distinguished from other genera within Acanthaceae based on the following three features: (i) a four-partite calyx consisting of two outer large segments and two smaller inner segments, (ii) globular, honeycombed pollen, and (iii) the prevalence of double cystoliths located in the epidermal cells $[33,40,45]$. The fruits of Barleria are hygrochastic [46], implying that the opening of the fruit is initiated by moisture or water $[47,48]$. In Barleria, the cystoliths are always double and lie in two adjacent cells. These structures are scattered over the leaf lamina and often lie parallel on the midrib [49-51]. Several species of Barleria are known for their medicinal or ornamental values $[37,52,53]$. There have been studies reviewing the traditional, phytochemical and pharmacological properties of specific species of Barleria (e.g., B. lupulina and B. prionitis) [54-56], however none have comprehensively reported on species within Barleria using exisiting literature in a clear and concise manner. Therefore, this review is intended to elaborate on only 
the important and extensively studied species belonging to the genus Barleria, with an emphasis on their biological activities that have been published.

\section{Phytochemical Evaluation of Barleria}

\subsection{Phytochemicals Isolated from Barleria}

Plants possess the ability to synthesize various secondary metabolites, among which at least 57182 have already been isolated [57]. It is important to determine the relationship between the phytochemical compounds of a medicinal plant and its pharmacological activity. A few of the highly important species of Barleria include B. prionitis, B. cristata, B. grandiflora, and B. lupulina [42,52]. Several authors have reported that species belonging to this genus exert biological effects, including antibacterial, antifungal, anti-inflammatory, anticancer, antidiabetic, antiulcer, hepatoprotective, analgesic, antiamoebic, antihelminthic, antiarthritic, antihypertensive, and antiviral activities and inhibition of acetylcholinesterase activity [58-65]. Studies have reported that bioactive compounds such as flavonoids, quinones, iridoids, phenylethanoid glycosides, immunostimulant protein "sankaranin," and antibiotics that are isolated from Barleria species are responsible for the abovementioned biological activities [66-70]. Jäger et al. [71] suggested that when bioactive compounds are detected in a plant species, it is possible that numerous species of the same genus contain active compounds of a similar nature. It has been reported that Barleria consists of various secondary metabolites that have been primarily isolated from the flowers, leaves, stems, roots, and seeds of the plant (Table 1). The important phytochemical compounds isolated from Barleria are iridoids, phenolic acids, phenylethanoid glycosides lignans, flavonoids, and phytosterols (Table 1 ).

Table 1. Chemical compounds isolated from the Genus Barleria.

\begin{tabular}{|c|c|c|c|c|}
\hline Plant Species & Plant Part & Chemical Group & Chemical Compounds/Phytoconstituents & Reference \\
\hline \multirow{5}{*}{ B. acanthoides } & \multirow{5}{*}{ Whole } & \multirow{2}{*}{ Phenolic glycosides } & Barlerisides A & \multirow{4}{*}{ [72] } \\
\hline & & & Barlerisides B & \\
\hline & & Phenylethanoid glycoside & Verbascoside (acteoside) & \\
\hline & & Phenolic acid & p-hydroxycinnamic acid & \\
\hline & & Neolignan diglycoside & Barlericin & [73] \\
\hline \multirow{16}{*}{ B. cristata } & \multirow{2}{*}{ Whole } & Phenolic acid & 4-hydroxy-trans-cinnamate & \multirow{2}{*}{ [70] } \\
\hline & & Terpenoid & oleanolic acid & \\
\hline & \multirow{8}{*}{ Bark } & \multirow{8}{*}{ Flavonoid } & $\begin{array}{l}\text { 6-O- } \alpha \text {-L-rhamnopyranoside-3,7,3'-O-trimethylated- } \\
\text { 8-hydroxyquercetin }\end{array}$ & \multirow{8}{*}{ [74] } \\
\hline & & & 6-O- $\alpha$-L-rhamnopyranoside quercetagetin & \\
\hline & & & 3-O-Methylquercetin & \\
\hline & & & Gossypetin 8-methyl ether & \\
\hline & & & Quercetagetin & \\
\hline & & & Tamarixetin & \\
\hline & & & Gossypetin & \\
\hline & & & Quercetin & \\
\hline & \multirow{6}{*}{ Leaves } & Phenolic acids & p-Coumaric acid & \multirow{6}{*}{ [75] } \\
\hline & & Lipid & $\alpha$-Tocopherol & \\
\hline & & Flavonoid & Luteolin & \\
\hline & & Flavonoid & 7-O-Methylluteolin & \\
\hline & & \multirow{2}{*}{ Iridoid glycosides } & Barlerin & \\
\hline & & & Shanzhiside methyl ester & \\
\hline
\end{tabular}


Table 1. Cont.

\begin{tabular}{|c|c|c|c|c|}
\hline Plant Species & Plant Part & Chemical Group & Chemical Compounds/Phytoconstituents & Reference \\
\hline & & \multirow{3}{*}{ Phenylethanoid glycosides } & Desrhamnosyl acteoside & \multirow{3}{*}[76]{} \\
\hline & & & Poliumoside & \\
\hline & & & Acteoside (verbascoside) & \\
\hline B. dinteri & Leaves & \multirow{18}{*}{ Iridoid glycosides } & Barlerin & [77] \\
\hline \multirow[t]{23}{*}{ B. lupulina } & Aerial & & 8-O-acetylipolamiidic acid & \multirow{23}{*}[78-84]{} \\
\hline & & & $\begin{array}{l}\text { 8-O-acetyl-6-O-( }(p \text {-methoxy-cis- } \\
\text { cinnamoyl)shanzhiside }\end{array}$ & \\
\hline & & & $\begin{array}{l}\text { 8-O-acetyl-6-O- }(p \text {-methoxy- } \\
\text { transcinnamoyl)shanzhiside }\end{array}$ & \\
\hline & & & $\begin{array}{l}\text { 6-O-p-methoxy-cis-cinnamoyl-8-O- } \\
\text { acetylshanzhiside } \\
\text { methyl ester }\end{array}$ & \\
\hline & & & $\begin{array}{l}\text { 6-O-p-methoxy-trans-cinnamoyl-8-O- } \\
\text { acetylshanzhiside } \\
\text { methyl ester }\end{array}$ & \\
\hline & & & $\begin{array}{l}\text { 6-O-p-cis-coumaroyl-8-O-acetylshanzhiside } \\
\text { methyl ester }\end{array}$ & \\
\hline & & & $\begin{array}{l}\text { 6-O-p-trans-coumaroyl-8-O-acetylshanzhiside } \\
\text { methyl ester }\end{array}$ & \\
\hline & & & Ipolamiide & \\
\hline & & & Ipolamiidoside & \\
\hline & & & Shanzhiside & \\
\hline & & & Shanzhiside methyl ester & \\
\hline & & & 8-O-acetylshanzhiside & \\
\hline & & & Barlerin & \\
\hline & & & 6-O-acetylshanzhiside methyl ester & \\
\hline & & & Acetylbarlerin & \\
\hline & & & Mussaenosidic acid & \\
\hline & & & Phlorigidoside & \\
\hline & & Iridoid diglucoside & Lupulinoside & \\
\hline & & \multirow{2}{*}{ Phenylethanoid glycosides } & Forsythoside & \\
\hline & & & Poliumoside & \\
\hline & & Lignan glucosides & $(+)$-lyoniresinol $3 \alpha$-O- $\beta$-glucopyranoside & \\
\hline & & Glycoside lipid molecule & 1-octen-3-yl- $\beta$-primeveroside & \\
\hline & & Glycoside & Benzyl $\beta$-primeveroside & \\
\hline B. noctiflora & Leaves & Phenylethanoid glycoside & Barlerinoside & [85] \\
\hline \multirow{3}{*}{ B. prionitis } & \multirow{3}{*}{ Aerial } & Terpenoid & Balarenone & {$[86]$} \\
\hline & & Phenylethanoid glycoside & Barlerinoside & [67] \\
\hline & & Phenylethanoid glycoside & Verbascoside & [87] \\
\hline
\end{tabular}


Table 1. Cont.

\begin{tabular}{|c|c|c|c|c|}
\hline Plant Species & Plant Part & Chemical Group & Chemical Compounds/Phytoconstituents & Reference \\
\hline & & \multirow{7}{*}{ Iridoid glycosides } & Barlerin & \multirow{2}{*}[65,67]{} \\
\hline & & & Acetylbarlerin & \\
\hline & & & Shanzhiside methyl ester & \multirow{3}{*}{ [87] } \\
\hline & & & $\begin{array}{l}\text { 6-O-trans- } p \text {-coumaroyl-8-O-acetylshanzhiside } \\
\text { methyl ester }\end{array}$ & \\
\hline & & & $\begin{array}{l}\text { 6-O-cis-coumaroyl-8-O-acetylshanzhiside } \\
\text { methyl ester }\end{array}$ & \\
\hline & & & 7-methoxydiderroside & \multirow{2}{*}{ [67] } \\
\hline & & & Lupulinoside & \\
\hline & & \multirow{2}{*}{ Terpenoid } & Pipataline & \multirow{3}{*}{ [87] } \\
\hline & & & Lupeol & \\
\hline & & \multirow{2}{*}{ Phytosterols } & 13,14-seco-stigmasta-5,14-diene-3- $\beta$-ol & \\
\hline & Roots & & $\beta$-sitosterol & [88] \\
\hline & Aerial & \multirow{4}{*}{ Flavonoid } & Apigenin $7-O-\beta$-D-glucoside & $\begin{array}{l}{[78,86,89,} \\
\quad 90]\end{array}$ \\
\hline & \multirow{2}{*}{ Leaves } & & 6-hydroxyflavone & \multirow{2}{*}{ [91] } \\
\hline & & & Scutellarin & \\
\hline & Aerial & & Luteolin-7-O- $\beta$-D-glucoside & [92] \\
\hline & \multirow{4}{*}{ Leaves } & \multirow{4}{*}{ Phenolic acid } & Melilotic acid & [93] \\
\hline & & & Syringic acid & \multirow{3}{*}{ [91] } \\
\hline & & & Vanillic acid & \\
\hline & & & p-hydroxybenzoic acid & \\
\hline \multirow{10}{*}{$\begin{array}{l}\text { B. strigose } \\
\text { Whole }\end{array}$} & & $\begin{array}{l}\text { Phenylethanoid } \\
\text { glycoside }\end{array}$ & $\begin{array}{l}\text { 4-hydroxyphenylethyl 4-O- } \beta \text {-D-glucopyranosyl- } \\
(1 \rightarrow 3)-O-\alpha \text {-L-rhamnopyranoside }\end{array}$ & \multirow{10}{*}[94]{} \\
\hline & & $\begin{array}{l}\text { Phenylethanoid } \\
\text { glycoside }\end{array}$ & Verbascoside & \\
\hline & & \multirow{5}{*}{ Iridoid glycoside } & 10-O-trans-coumaroyl-eranthemoside & \\
\hline & & & Decaffeoylverbascoside & \\
\hline & & & Lyoniresinol $3 \alpha-O-\beta$-D-glucoside & \\
\hline & & & 7-O-acetyl-8-epi-loganic acid & \\
\hline & & & $\begin{array}{l}(3 \mathrm{R})-1 \text {-octen-3-ol-3-O- } \beta \text {-D-xylosyl- }(1 \rightarrow 6)-\beta \text {-D- } \\
\text { glucoside }\end{array}$ & \\
\hline & & \multirow{2}{*}{ Phenylethanoid glycosides } & Isoverbascoside & \\
\hline & & & Decaffeoylverbascoside & \\
\hline & & Flavonoid & Apigenin $7-O-\alpha$-Lrhamnosyl- $(1 \rightarrow 6)-O-\beta$-D-glucoside & \\
\hline \multirow{4}{*}{ B. trispinosa } & \multirow{4}{*}{ Aerial } & \multirow{4}{*}{ Iridoid glycosides } & $\begin{array}{l}\text { 6- } \alpha \text {-L-rhamnopyranosyl-8-O-acetylshanzihiside } \\
\text { methyl ester }\end{array}$ & \multirow{4}{*}{ [95] } \\
\hline & & & Acetyl barlerin & \\
\hline & & & Barlerin & \\
\hline & & & Shanzhiside methyl ester & \\
\hline
\end{tabular}

\subsubsection{Iridoids}

Chemical compounds such as iridoids are monoterpenes that are biosynthesized from isoprene and are also identified to be precursors in the biosynthesis of alkaloids [96-99]. 
Like glycosides, iridoids are generally found in various medicinal plants and are most often bound to glucose $[96,97]$. Iridoids that are isolated and purified exhibit a broad spectrum of bioactivities, including antihepatotoxic, choleretic, hypoglycemic, cardiovascular, anti-inflammatory, antimutagenic, antitumor, antiviral, and analgesic activities [96,97]. Some important iridoid medicinal compounds found in Barleria include barlerin, shanzhiside methyl ester, ipolamiide, acetylbarlerin, phlorigidoside, lupulinoside, 7-methoxydiderroside, isoverbascoside, decaffeoylverbascoside, and 10-O-trans-coumaroyleranthemoside (Table 1).

\subsubsection{Phenolic Compounds (Acids/Glycosides/Lignans/Neolignans)}

Phenolic acids are natural compounds that are prevalent throughout the plant kingdom. They are involved in a variety of biological activities such as antimicrobial, antiinflammatory, antioxidant, antidiabetic, hepatoprotective, and anticancer properties [98,100-103]. Phenolic acids can be categorized into hyrdoxybenzoic acids that contain seven carbon atoms and cinnamic acids that contain nine carbon atoms (C6-C3). Phenolic compounds derived from plants are different in their molecular structure and are typically characterized by their hydroxylated aromatic rings [104]. In several plants, phenolic compounds are polymerized into large molecules such as lignins and proanthocyanidins (condensed tannins). The antioxidant capacity of phenolic compounds has attracted the attention of researchers, as these compounds can reduce the risk of developing several diseases and protect the human body from free superoxide radicals [105]. The important phenolic acids found in Barleria include $p$-hydroxycinnamic acid, $p$-coumaric acid, $\alpha$-tocopherol, melilotic acid, syringic acid, vanillic acid, and $p$-hydroxybenzoic acid (Table 1 ). The aromatic compound 4-hydroxy-trans-cinnamate derivative found in Barleria was isolated from B. cristata [70]. The phenolic glycosides found in this genus are barlerisides A and B (Table 1).

Lignans and neolignans are a group of large, naturally occurring phenols that are derived from the shikimic acid biosynthetic pathway and have a wide distribution within the plant kingdom [106]. Both class of compounds exhibit dimeric structures that are formed by a $\beta$-linkage between the two phenyl propane units and an altered degree of oxidation in the side chain [106]. One of the major ecological functions of lignans is protecting the plants that synthesize them against herbivores and microorganisms [107].

One lignan glucoside, (+)-lyoniresinol $3 \alpha-O-\beta$-glucopyranoside, was isolated from the aerial plant parts of B. lupulina (Table 1). In B. acanthoides, one type of neolignan diglycoside, barlericin, was isolated from the entire plant (Table 1).

\subsubsection{Flavonoids}

Flavonoids are present in the leaves, flowers, and pollen of several plants and comprise a group of polyphenolic compounds [108]. Flavones, flavanones, flavonols, isoflavones, and anthocyanins are the major classes of flavonoids that have been reported to possess a broad spectrum of biological and therapeutic activities [109]. Studies have also reported that flavonoids or flavonoid-rich extracts exhibit antioxidant, anti-inflammatory, and antimicrobial activities [110-114]. Flavonoids play a vital role in inhibiting the activity of important enzymes in mitochondrial respiration and in protection against heart diseases [115]. This compound has the potential to prevent early stages of cancer due to its ability to scavenge free radicals [116]. A total of 14 flavonoids (Table 1) have been isolated from various plant parts of Barleria, including 6-O- $\alpha$-L-rhamnopyranoside3,7,3'-O-trimethylated-8-hydroxyquercetin, 6-O- $\alpha$-L-rhamnopyranoside quercetagetin, 3$O$-methylquercetin, gossypetin 8-methyl ether, quercetagetin, tamarixetin, gossypetin, quercetin, luteolin, 7-O-methylluteolin, apigenin 7-O- $\beta$-D-glucoside, 6-hydroxyflavone, apigenin 7-O- $\alpha$-L-rhamnosyl-( $1 \rightarrow 6)-O-\beta$-D-glucoside, scutellarin, and luteolin-7-O- $\beta$-D-glucoside.

\subsubsection{Terpenoids}

Terpenoids are the most frequent and structurally diverse organic compounds that are derived from five-carbon isoprene units [117]. Terpenoids are classified based on the 
number of isoprene units, such as hemiterpenoids (C5), monoterpenoids (C10), sesquiterpenoids (C15), diterpenoids (C20), sesterterpenoids (C25), and triterpenoids (C30) [117,118]. A large number of terpenoids are of plant origin and have several biological roles in higher plants $[119,120]$. In addition, four terpenoid compounds, oleanolic acid, balarenone, pipataline, and lupeol, were isolated from the aerial parts and the entire plant of Barleria (Table 1). The terpenoids isolated from plant extracts are known to possess antiviral, antifungal, antibacterial, anti-inflammatory, antihyperglycemic, anticancer, and insecticidal properties [121].

\subsubsection{Phytosterols (Terpernoids)}

Phytosterols are an important family of lipids that are typically found in plants and fungi and are essential to humans because of their nutritional and medicinal values. Phytosterols also function as precursors in the production of essential bioactive compounds such as steroidal glycoalkaloids, steroidal saponins, brassinosteroids, and phytoecdysteroids [122]. They are grouped into 24-ethylsterols and 24-methylsterols [123]. Some examples of 4-desmethylsterols that are abundantly found in most of the plants are campesterol, sitosterol, and stigmasterol [124]. Only two isolated phytosterols have been reported in B. prionitis, viz., 13,14-seco-stigmasta-5,14-diene-3- $\beta$-ol and $\beta$-sitosterol (Table 1).

\subsubsection{Phenylethanoid Glycosides}

Phenylethanoid glycosides are a group of aqueous-soluble compounds, with majority of them have been isolated from medicinal plants [125,126]. The general structure of phenylethanoid glycosides has one glucopyranoside unit linked to the phenethyl alcohol. This compound has chemotaxonomic relevance being considered with one additional chemotaxonomic marker in several families of Asterids, in particular when in co-occurrence with iridoids [127]. Phenylethanoid glycosides have been described to contain novel structures with diverse bioactivities [128,129]. Five phenylethanoid glycosides, viz., acteoside (synonym verbascoside), desrhamnosyl acteoside, poliumoside, forsythoside and barlerinoside, have been isolated from several species of Barleria. However, verbascoside (synonym acetoside), was isolated from B. acanthoides, B. prionitis, and B. strigosa (Table 1).

\section{Biological Activities of Extracts, Fractions, and Isolated Compounds from Barleria}

\subsection{Antioxidant Properties}

Antioxidants are defined as substances that inhibit or delay oxidative damage to a specific molecule [130]. Oxidative stress is a key contributor to various chronic diseases [131]. It implies a disruption in the imbalance between reactive oxygen species (ROS), free radicals (FR), and the endogenous antioxidant defense mechanisms [132]. When antioxidant molecules encounter single FR, they neutralize them by donating one of their own electrons, which in turn ends the carbon-stealing reaction [133,134]. The antioxidant defense mechanisms in plants are enzymatic and nonenzymatic. The enzymatic defense mechanism includes catalase (CAT), peroxidase (POX), and superoxide dismutase. These antioxidants effectively mitigate cell damage against ROS. The nonenzymatic antioxidant mechanism consists of carotenoids, vitamin C, vitamin E, and flavonoids [135-137]. There is substantial evidence indicating that FR cause oxidative damage to biomolecules (nucleic acids, lipids, and proteins), which eventually results in aging, atherosclerosis, diabetes mellitus, cancer, acquired immunodeficiency syndrome (AIDS), inflammation, and various degenerative diseases in humans [138]. Plants are a source of natural antioxidants, including phenols, flavonoids, ascorbic acid, and carotenoids. Ascorbic acid and $\beta$-carotene are one of the widely used antioxidants [139].

The reported antioxidant properties of various extracts and isolated compounds of Barleria are summarized in Table 2. Various methods have been used to evaluate the antioxidant activities of aqueous, acetone, ethanol, ethyl acetate, hydroalcoholic and methanolextracts and those of the isolated compounds barlerisides A and B, shanzhiside methyl ester, 6-O-trans- $p$-coumaroyl-8-O-acetylshanzhiside, methyl ester, barlerin, acetylbarlerin, 
7-methoxydiderroside, and lupulinoside. Antioxidant activity was observed and reported in all plant extracts by several researchers using various assays. The most frequently investigated species within the genus is B. prionitis. Amoo et al. [98] examined the methanolic extracts of the different parts of B. prionitis using the 1,1-diphenyl-2-picrylhydrazyl (DPPH) scavenging assay and reported that the extracts exhibited free radical scavenging activity, with the $\mathrm{EC}_{50}$ values varying from 6.65 to $12 \mu \mathrm{g} / \mathrm{mL}$. In addition, they evaluated the ferric reducing antioxidant power and the $\beta$-carotene bleaching rate of the extracts and found that the extracts reduced the ferric ion complex to the ferrous form and decreased the carotenoid bleaching rate. The findings of that study suggest the occurrence of antioxidant compounds in the methanol extracts, which are capable of donating electrons and hydrogen atoms in their reactions [98]. Moreover, Jaiswal et al. [140] evaluated the $\beta$-carotene bleaching potential, and the hydroxyl radical scavenging activity of the ethanolic extracts of B. prionitis. They found the highest $\beta$-carotene bleaching rate of $79.20 \% \pm 1.26 \%$ compared to those of flower $(62.16 \% \pm 2.56 \%)$ and stem $(48.31 \% \pm 1.960 \%)$ extracts. The leaf extract exhibited good free radical scavenging activities compared to the other plant extracts, with the $\mathrm{IC}_{50}$ values being $336.15 \pm 7.21 \mu \mathrm{g} / \mathrm{mL}$ for DPPH and $568.65 \pm 6.11 \mu \mathrm{g} / \mathrm{mL}$ for the hydroxyl radical. Quercetin was used as the standard for DPPH and hydroxyl radicial with $\mathrm{IC}_{50}$ values of $0.021 \pm 0.004 \mathrm{ug} / \mathrm{mL}$ and $0.072 \pm 0.007 \mathrm{ug} / \mathrm{mL}$, respectively. Various species within the genus Barleria exhibit excellent antioxidant properties. Therefore, the antioxidants found in Barleria plant extracts exhibiting free radical scavenging activities may play an important role as therapeutic agents in numerous diseases that are related to oxidative stress [141].

Table 2. Antioxidant properties of extracts and compounds isolated from Barleria.

\begin{tabular}{|c|c|c|c|c|}
\hline Plant Species & Plant Part & Extract/Compound & Antioxidant Activity/Models/Assays & Reference \\
\hline B. acanthoides & Whole & Barleriside A, barleriside B & $\begin{array}{l}\text { Superoxide scavenging activity, Xanthine } \\
\text { oxidase activity }\end{array}$ & [72] \\
\hline B. albostellata & $\begin{array}{l}\text { Leaves, } \\
\text { stems }\end{array}$ & Methanol & $\begin{array}{l}\text { DPPH assay; FRAP assay; } \beta \text {-Carotene-linoleic acid } \\
\text { model system }\end{array}$ & [98] \\
\hline B. argillicola & Whole & Methanol & $\beta$-Carotene-linoleic acid model system; DPPH assay & [142] \\
\hline B. courtrallica & Leaves & Ethanol & $\begin{array}{l}\text { DPPH assay, hydroxyl radical scavenging activity, } \\
\text { superoxide radical scavenging activity, ABTS assay } \\
\text { and reducing power methods. }\end{array}$ & [143] \\
\hline \multirow{4}{*}{ B. cristata } & Leaves & Ethanol & $\begin{array}{l}\text { DPPH assay, Superoxide anion and nitric oxide } \\
\text { radical scavenging activity, hydrogen peroxide } \\
\text { scavenging activity }\end{array}$ & [144] \\
\hline & Leaves & Ethanol & DPPH assay, ABTS assay, TPTZ assay & [145] \\
\hline & Leaves & Acetone and methanol & DPPH assay; Nitric-oxide Reducing Assay, FRAP & [146] \\
\hline & Leaves & Ethanol & DPPH assay, FRAP & [147] \\
\hline B. dinteri & Leaves & Acetone and methanol & DPPH assay & [148] \\
\hline B. gibsoni & Leaves & Ethanol & DPPH assay; Nitric oxide radical scavenging activity & [53] \\
\hline B. grandiflora & Leaves & Water and ethanol & FTC method, TBA method & [149] \\
\hline B. greenii & $\begin{array}{l}\text { Leaves, } \\
\text { stems, } \\
\text { roots }\end{array}$ & Methanol & $\begin{array}{l}\text { DPPH assay; FRAP assay; } \beta \text {-Carotene-linoleic acid } \\
\text { model system }\end{array}$ & [98] \\
\hline B. lupulina & $\begin{array}{l}\text { Leaves, } \\
\text { stems }\end{array}$ & Methanol & DPPH assay & [42] \\
\hline \multirow[t]{2}{*}{ B. montana } & Leaves & Ethanol & $\begin{array}{l}\text { DPPH, Reducing power assay, Nitric oxide } \\
\text { scavenging activity }\end{array}$ & [150] \\
\hline & Leaves & Methanol & DPPH assay, Hydrogen peroxide method & [151] \\
\hline
\end{tabular}


Table 2. Cont.

\begin{tabular}{|c|c|c|c|c|}
\hline Plant Species & Plant Part & Extract/Compound & Antioxidant Activity/Models/Assays & Reference \\
\hline B. mysorensis & Leaves & Water & DPPH assay & [152] \\
\hline \multirow{5}{*}{ B. noctiflora } & Leaf, roots & Methanol & $\begin{array}{l}\text { DPPH assay, Ferrous reducing power, } \mathrm{Fe}^{2+} \text { reducing } \\
\text { power, } \mathrm{Fe}^{2+} \text { chelating activity assay, Nitric oxide } \\
\text { scavenging activity, ABTS assay, Superoxide anion } \\
\text { scavenging activity, Hydrogen peroxide radical } \\
\text { scavenging activity }\end{array}$ & [153] \\
\hline & Whole & Ethanol & DPPH assay & [154] \\
\hline & Aerial & Ethanol and Water & $\begin{array}{l}\text { DPPH assay, ABTS assay, Scavenging of hydrogen } \\
\text { peroxide }\left(\mathrm{H}_{2} \mathrm{O}_{2}\right) \text {, Lipid Peroxidation Inhibitory } \\
\text { Activity, Hydroxyl radical scavenging activity } \\
\text { p-NDA method, Superoxide radical scavenging } \\
\text { activity by alkaline DMSO method }\end{array}$ & [155] \\
\hline & $\begin{array}{l}\text { Leaves, } \\
\text { stems, } \\
\text { roots }\end{array}$ & Methanol & $\begin{array}{l}\text { DPPH assay; FRAP assay; } \beta \text {-Carotene-linoleic acid } \\
\text { model system }\end{array}$ & [98] \\
\hline & Aerial & Ethanol & $\begin{array}{l}\beta \text { carotene bleaching assay, DPPH assay and } \\
\text { hydroxyl radical scavenging activity }\end{array}$ & [140] \\
\hline
\end{tabular}

Shanzhiside methyl ester, 6-O-trans- $p$-coumaroyl-8O-acetylshanzhiside Aerial methyl ester, barlerin, DPPH assay acetylbarlerin, 7-methoxydiderroside, lupulinoside

B. prionitis

\begin{tabular}{llll}
\hline Whole & Ethyl acetate & DPPH assay & {$[156]$} \\
\hline $\begin{array}{l}\text { Leaves, } \\
\text { stems }\end{array}$ & Acetone & FRAP assay, DPPH assay, ABTS Assay & {$[157]$} \\
\hline $\begin{array}{l}\text { Leaves, } \\
\text { stems }\end{array}$ & Methanol & DPPH, Reducing power assay & {$[158]$} \\
\hline $\begin{array}{l}\text { Bark, } \\
\text { leaves }\end{array}$ & Methanol & DPPH assay & {$[159]$} \\
\hline Leaves & Ethanol & $\begin{array}{l}\text { FTC method, TBA method, Scavenging of hydrogen } \\
\text { peroxide radicals, DPPH assay }\end{array}$ & {$[160]$} \\
\hline Whole & Ethanol & $\begin{array}{l}\text { DPPH, ABTS Assay, Hydroxyl radical scavenging } \\
\text { activity, Reducing power assay, Nitrous oxide } \\
\text { Reducing Assay }\end{array}$ & [69] \\
\hline Flower & Ethanol and water & DPPH assay & {$[161]$} \\
\hline Roots & Ethanol and water & $\begin{array}{l}\text { ABTS assay, Nitric oxide quenching assay, Ferric } \\
\text { reducing assay, DPPH, }\end{array}$ & {$[162]$} \\
\hline Leaves & Methanol & DPPH assay & {$[163]$} \\
\hline
\end{tabular}

DPPH-(1,1-Diphenyl-2-picrylhydrazyl) free radical-scavenging activity; FRAP_Ferric Reducing Antioxidant Power, ABTS- (2,2' -azino-bis(3-ethylbenzothiazoline-6-sulfonic acid)) free radical-scavenging activity; FTCFerric thiocyanate method; TBA-Thiobarbituric acid method; TPTZ-2,4,6-tripyridyl-s-triazine radical scavenging assay; TBA-Thiobarbituric acid method.

\subsection{Antibacterial Activity}

Infectious diseases are a serious concern in Africa [164]. One of the primary causes of ill health and death are bacterial infections [165-167]. The extensive use of antibiotics to treat bacterial infections has encouraged researchers to screen medicinal plants for antibacterial activity [168]. Plant species belonging to the genus Barleria (Acanthaceae) are known to exhibit exceptional antibacterial properties. Several studies have demonstrated the an- 
tibacterial activity of extracts and isolated compounds of Barleria (Table 3). The antibacterial activity of the various plant extracts has been evaluated against the Gram-positive bacteria Bacillus cereus, Bacillus pumilus, Bacillus sp., Bacillus subtilis, Enterococcus faecalis, Lactobacillus acidophilus, Lactobacillus rhamnosus, Lactobacillus sporogenes, Micrococcus luteus, Staphylococcus aureus, Staphylococcus epidermidis, Streptococcus mutans, and Streptococcus pyogenes and the Gram-negative bacteria Comamonas acidovorans, Citrobacter sp., Enterobacter aerogenes, Escherichia coli, Klebsiella pneumoniae, Pseudomonas aeruginosa, Pseudomonas fluorescens, Proteus mirabilis, Providencia sp., Pseudomonas sp, Proteus vulgaris, Salmonella paratyphi, Salmonella typhi, Shigella dysenteriae, Serratia marcescens, Vibrio cholera, and Xanthomonas oryzae. The most commonly investigated species for the antibacterial activity within the genus is B. prionitis. Amoo et al. [66] examined the minimum inhibitory concentration (MIC) of the petroleum ether, dichloromethane, and ethanol extracts of B. prionitis. Neomycin was used as a positive control against each bacterium.

Table 3. Antibacterial activities of extracts from species within Barleria.

\begin{tabular}{|c|c|c|c|c|c|}
\hline $\begin{array}{l}\text { Plant } \\
\text { Species }\end{array}$ & Plant Part & Extract & Antibacterial Activity & $\begin{array}{l}\text { Agent Dosage } \\
(\mu \mathrm{g} / \mathrm{mL})\end{array}$ & Reference \\
\hline B. acuminata & Leaves & Ethanol & $\begin{array}{l}\text { B. cereus, B. subtilis, E. faecalis, } \\
\text { S. aureus, S. epidermidis, E. coli, } \\
\text { K. pneumonia, P. mirabilis, S. typhi, } \\
\text { S. dysentriae. }\end{array}$ & 50,000 & [170] \\
\hline B. albostellata & Leaves, stem & $\begin{array}{l}\text { Petroleum ether, } \\
\text { dichloromethane }\end{array}$ & $\begin{array}{l}\text { B. subtillis, S. aureus, E. coli, } \\
\text { K. pneumoniae }\end{array}$ & 50,000 & {$[66]$} \\
\hline B. argillicola & Whole & Methanol & E. coli, $P$. aeruginosa, S. aureus & 20,000 & [142] \\
\hline \multirow{4}{*}{ B. cristata } & Bark & Ethanol & S. aureus, B. subtillis, S. mutans & 10,000 & {$[74]$} \\
\hline & \multirow{3}{*}{ Leaves } & Methanol & $\begin{array}{l}\text { K. pneumonia, S. aureus, E. coli, } \\
\text { S. paratyphi }\end{array}$ & 5000 & [144] \\
\hline & & Methanol and water & S. pyogenes, E. coli & 300 & {$[171]$} \\
\hline & & $\begin{array}{l}\text { Petroleum ether, } \\
\text { chloroform and water }\end{array}$ & $\begin{array}{l}\text { X. oryzae, B. subtilis, E. coli, } \\
\text { P. aeruginosa, P. fluorescences. }\end{array}$ & - & [172] \\
\hline B. dinteri & Leaves & $\begin{array}{l}\text { n-hexane, } \\
\text { dichloromethane, } \\
\text { acetone and methanol }\end{array}$ & $\begin{array}{l}\text { E. coli, E. faecaelis, S. aureus, } P \text {. } \\
\text { aeruginosa. }\end{array}$ & 10,000 & [148] \\
\hline B. grandiflora & Aerial & Ethanol & S. aureus; S. mutans & 5000 & [173] \\
\hline B. greenii & Stems, roots & Dichloromethane & $\begin{array}{l}\text { B. subtillis, S. aureus, E. coli, } \\
\text { K. pneumoniae }\end{array}$ & 30,000 & [66] \\
\hline \multirow{5}{*}{ B. lupulina } & Whole & Methanol & Propionibacterium acnes & - & {$[64]$} \\
\hline & leaves & Methanol & $\begin{array}{l}\text { S. aureus, E. coli; P. aeruginosa, } \\
\text { K. pneumoniae, S. typhi }\end{array}$ & 200,000 & [42] \\
\hline & Leaves, stems & Ethanol & $\begin{array}{l}\text { S. aureus, E. coli, P. aeruginosa, } \\
\text { K. pneumonia, S. typhi }\end{array}$ & 20,000 & [174] \\
\hline & Leaves & Methanol & S. aureus, B. pumilus & 1250 & [175] \\
\hline & Leaves & Essential oil & B. pumilus, S. aureus & - & [176] \\
\hline B. montana & Leaves & Acetone & $\begin{array}{l}\text { E. coli; S. typhi; P. aeruginosa; } \\
\text { K. pneumoniae; P. vulgaris; B. } \\
\text { subtilis; S. pneumoniae; S. aureus; } \\
\text { E.coli }\end{array}$ & 200 & [177] \\
\hline
\end{tabular}


Table 3. Cont.

\begin{tabular}{|c|c|c|c|c|c|}
\hline $\begin{array}{l}\text { Plant } \\
\text { Species }\end{array}$ & Plant Part & Extract & Antibacterial Activity & $\begin{array}{l}\text { Agent Dosage } \\
(\mu \mathrm{g} / \mathrm{mL})\end{array}$ & Reference \\
\hline & Aerial & Methanol & $\begin{array}{l}\text { B. subtilis; B. cereus; B. pumilis; } \\
\text { S. aureus; } \\
\text { E. coli; P. aeuriginosa; P. vulgaris; } \\
\text { S. marceseans }\end{array}$ & 200,000 & [178] \\
\hline & Leaves & $\begin{array}{l}\text { Water, ethanol, } \\
\text { methanol, chloroform }\end{array}$ & $\begin{array}{l}\text { E. aerogenes; E. coli; S. pneumoniae; } \\
\text { B.subtilis; P. vulgaris }\end{array}$ & 100 & [179] \\
\hline \multirow{10}{*}{ B. prionitis } & Leaves, stems & Dichloromethane & $\begin{array}{l}\text { B. subtilis, S. aureus, E. coli, } \\
\text { K. pneumoniae }\end{array}$ & 50,000 & [66] \\
\hline & Bark & Methanol & $\begin{array}{l}\text { S. mutants, S. aureus, } \\
\text { Pseudomonas sp., Bacillus sp. }\end{array}$ & 50,000 & [169] \\
\hline & Leaves & Chloroform & $\begin{array}{l}\text { S. typhi; B. subtilis; V. cholera; } \\
\text { M. luteus; Providencia sp.; } \\
\text { L. sporogenus, Citrobacter sp. }\end{array}$ & 50,000 & [180] \\
\hline & Leaves & $\begin{array}{l}\text { Water, petroleum ether, } \\
\text { chloroform, acetone }\end{array}$ & L. rhamnosus & 200,000 & [181] \\
\hline & Leaves & Ethanol & $\begin{array}{l}\text { S. typhi; B. subtilis; } \\
\text { S. aureus; V. cholera; E. coli }\end{array}$ & 10,000 & [182] \\
\hline & Leaves, stem & Ethyl acetate & $\begin{array}{l}\text { B. pumilus; B. subtilis; S. pyogenes; } \\
\text { B. cereus; S. marcescens, } \\
\text { C. acidovorans; P. aeruginosa }\end{array}$ & 100,000 & [183] \\
\hline & Leaves & Methanol & $\begin{array}{l}\text { S. mutants; S. aureus; L. acidophilus; } \\
\text { Pseudomonas sp. }\end{array}$ & 10,000 & [184] \\
\hline & Leaves & $\begin{array}{l}\text { Petroleum ether, } \\
\text { chloroform, water }\end{array}$ & $\begin{array}{l}\text { B. subtilis; E. coli; P. fluorescens; } \\
\text { X. oryzae }\end{array}$ & - & [172] \\
\hline & Leaves & Ethanol & $\begin{array}{l}\text { S. aureus; B. subtilis; P. vulgaris; } \\
\text { K. pneumonia; E. coli; P. aeruginosa }\end{array}$ & 10,000 & [185] \\
\hline & Aerial & Ethanol & B. cereus; $P$. aeruginosa & - & [86] \\
\hline B. strigosa & Leaves & Butanol & B. subtilis; S. aureus; M. luteus & 2000 & [186] \\
\hline
\end{tabular}

These authors and found that these extracts exhibited a broad spectrum of antibacterial activity. The MIC values ranged from 781 to $3125 \mu \mathrm{g} / \mathrm{mLfor}$ B. subtilis, S. aureus, E. coli, and K. pneumoniae. These MIC values were compared to neomycin which ranged from 1000 to $1563 \mu \mathrm{g} / \mathrm{mL}$. MIC values were $(>100 \mu \mathrm{g} / \mathrm{mL})$ from the tested extracts and were considered moderately effective when compared to neomycin, while others displayed low antibacterial activity. Findings from this study demonstrated the potential of B. prionitis as an antibacterial agent, while further studies are necessary. Furthermore, Aneja et al. [169] evaluated the antibacterial activity of the acetone, ethanol, methanol, and water extracts of B. prionitis bark. Ciprofloxacin served as the positive control. Their study results suggested that the methanolic bark extract $(100 \mu \mathrm{g} / \mathrm{mL})$ was the most effective against all four oral bacteria with varying inhibition zones (S. mutans $(15.65 \pm 0.57 \mathrm{~mm})$, S. aureus $(16.32 \pm 0.57 \mathrm{~mm})$, Pseudomonas sp. (19.32 $\pm 0.57 \mathrm{~mm})$, and Bacillus sp. $(28.65 \pm 0.57 \mathrm{~mm})$ Zones of inhibition values of the tested extract were compared to ciprofloxacin $(100 \mu \mathrm{g} / \mathrm{mL})$ which ranged from $27.32 \pm 0.57 \mathrm{~mm}$ to $29.65 \pm 0.57 \mathrm{~mm}$. Therefore, the methanolic bark extract displayed promising antibacterial activity when compared to ciprofloxacin. 
Statistical analyses on the antibacterial activity of crude extracts are lacking in both studies, this should be further explored.

\subsection{Antifungal Activity}

Opportunistic fungal infections can become fatal to individuals with immunocompromised conditions [187], in particular those with cancer [188] and HIV/AIDS [189]. Management of these infections has become complex due to the limited number of cost effective antifungal agents, toxicity of the accessible agents, relapse of infections, and resistance to these commonly used agents $[190,191]$. Consequently, it has become critical to explore naturally occurring antifungal agents. Barleria, being one of such genera, has exhibited excellent antifungal properties. Numerous studies have validated the antifungal activity of the extracts and fractions of Barleria (Table 4). Aneja et al. [169] evaluated the antifungal activity of acetone, ethanol, and methanolic extracts of B. prionitis and found that the extracts significantly reduced the growth of fungi, with the maximum zone of inhibition being observed for Candida albicans $(100 \mu \mathrm{g} / \mathrm{mL})$ strain $1(13.65 \pm 0.57,12.94 \pm 1$, and $15.31 \pm 0.57 \mathrm{~mm})$, C. albicans $(100 \mu \mathrm{g} / \mathrm{mL})$ strain $2(16 \pm 0,11.31 \pm 0.57$, and $16.96 \pm 1 \mathrm{~mm})$, and Saccharomyces cerevisiae $(100 \mu \mathrm{g} / \mathrm{mL})(11.64 \pm 0.57,11.31 \pm 0.57$, and $13.95 \pm 1 \mathrm{~mm})$. Amphotericin-B $(100 \mu \mathrm{g} / \mathrm{mL})$ served as the positive control, with inhibition zones ranging from $11.94 \pm 1 \mathrm{~mm}$ to $13 \pm 0$. Results of the tested extracts were similar to/ or higher then amphotericin-B, thus displaying siginificant antifungal activity.

Table 4. Antifungal activities of extracts from species within Barleria.

\begin{tabular}{|c|c|c|c|c|c|}
\hline $\begin{array}{l}\text { Plant } \\
\text { Species }\end{array}$ & Plant Part & Extract & Antifungal Activity & $\begin{array}{l}\text { Agent Dosage } \\
(\mu \mathrm{g} / \mathrm{mL})\end{array}$ & Reference \\
\hline B. albostellata & $\begin{array}{l}\text { Leaves and } \\
\text { stems }\end{array}$ & $\begin{array}{l}\text { Petroleum ether, } \\
\text { dichloromethane }\end{array}$ & C. albicans & 20,000 & [98] \\
\hline \multirow{3}{*}{ B. cristata } & \multirow{3}{*}{ Leaves } & Saponin fraction & $\begin{array}{l}\text { C. albicans; A. flavous; Penicillium sp.; } \\
\text { A. niger; Trichophyton sp. }\end{array}$ & 1000 & [192] \\
\hline & & Saponin fraction & A. flavous; A. niger & 5000 & [144] \\
\hline & & $\begin{array}{l}\text { Petroleum ether, } \\
\text { chloroform, water }\end{array}$ & A. flavous; C. albicans & - & [172] \\
\hline \multirow{3}{*}{ B. grandiflora } & Leaves & Water & A. fumigatus & 625 & [193] \\
\hline & Aerial & Ethanol & C. albicans & 5000 & [173] \\
\hline & Leaves & Ethanol & C. albicans & 1600 & [194] \\
\hline B. greenii & $\begin{array}{l}\text { Leaves, stems } \\
\text { and roots }\end{array}$ & Dichloromethane & C. albicans & 20,000 & [98] \\
\hline B. montana & Aerial & Methanol & $\begin{array}{l}\text { A. niger; } R \text {. stolonifera; S. cerevisiae; } \\
\text { P. chrysogenum }\end{array}$ & 200,000 & [178] \\
\hline \multirow{7}{*}{ B. prionitis } & Bark & Methanol & S. cerevisiae; C. albicans & 50,000 & [169] \\
\hline & $\begin{array}{l}\text { Roots and } \\
\text { stems }\end{array}$ & $\begin{array}{l}\text { Petroleum ether, } \\
\text { dichloromethane }\end{array}$ & C. albicans & 20,000 & {$[98]$} \\
\hline & $\begin{array}{l}\text { Leaves, stems } \\
\text { and roots }\end{array}$ & Ethanol & $\begin{array}{l}\text { A. fumigatus; C. vaginitis; } \\
\text { C. neoformans; C. albicans; } \\
\text { B. dermatitidis }\end{array}$ & 20,000 & [195] \\
\hline & Aerial & Ethanol & C. albicans & 5000 & [173] \\
\hline & Leaves & Ethanol & C. albicans & 1600 & [194] \\
\hline & \multirow{2}{*}{ Aerial } & Methanol & C. albicans & 200 & [196] \\
\hline & & Methanol & C. albicans, A. niger & 200,000 & [197] \\
\hline
\end{tabular}


Furthermore, Amoo et al. [98] demonstrated the fungicidal activity of extracts derived from different parts of B. prionitis against C. albicans. Amphotericin B was used as a positive control in this study. They reported a minimum fungicidal concentration range of $4700-6300 \mu \mathrm{g} / \mathrm{mL}$ for the extracts of stems and roots. Minimum fungicidal concentration (MFC) for amphotericin B was $0.193 \mu \mathrm{g} / \mathrm{mL}$. Therefore, the tested extracts displayed low antifungal activity $(<100 \mu \mathrm{g} / \mathrm{mL})$ when compared to the positive control. Statistical analyses on the antifungal activity of crude extracts are lacking in both studies, this should be further explored.

\subsection{Anti-Inflammatory Activity}

Several deteriorating diseases such as shoulder tendonitis, gouty arthritis, rheumatoid arthritis, polymyalgia rheumatica, asthma, cancer, heart disease, and inflammatory bowel disease are related to inflammatory processes [93,198,199]. Scientific researchers and pharmaceutical companies have been showing a growing interest in identifying novel anti-inflammatory compounds in medicinal plants. This can potentially lead to the production of novel drugs in treating pain-related ailments with no side effects [200]. Several studies have validated the anti-inflammatory activity of the extracts and fractions of Barleria (Table 5). Amoo et al. [66] evaluated the anti-inflammatory activity of petroleum ether, dichloromethane, and ethanolic extracts using cyclooxygenase (COX)-1 and COX-2 assays. The positive control used was indomethacin, with a concentration of $5 \mu \mathrm{M}$ for COX-1 and $200 \mu \mathrm{M}$ for COX-2. They reported that petroleum ether extracts (leaf $(72.5 \% \pm 1.26 \%)$ and $\operatorname{root}(77.2 \% \pm 1.41 \%)$ and dichloromethane extracts (leaf $(79.7 \% \pm 1.55 \%)$ ) of B. prionitis exhibited promising activity $(>70 \%)$ in COX-1 assay. Indomethacin inhibited prostaglandin synthesis in COX-1 assay with a value of $63.4 \pm 1.98 \%$. Moreover, in COX-2 assays, the root, petroleum ether $(78.5 \% \pm 1.90 \%)$, and dichloromethane extracts $(70.4 \% \pm 1.80 \%)$ of B. prionitis demonstrated the best activity $(>70 \%)$. The nonpolar extracts (petroleum ether and dichloromethane) exhibited greater activity than ethanolic extract. Additionally, for COX-2 assay, indomethacin inhibited prostaglandin synthesis (73.6 $\pm 1.47 \%)$. Statistical analysis showed extracts had significantly different activity $(p<0.05)$. Overall, extracts, to some degree, presented good anti-inflammatory activity. Cos et al. [192] reported that compounds that are strong inhibitors of enzymes fail in vitro to settle against the entire organism, as their passage toward the cell membrane is restricted. In addition, Zschocke and Van Staden [201] explained that the activity exhibited by nonpolar extracts is of significant interest because the lipophilic compounds extracted from these solvents exhibit better resorption through the cell membrane. Overall, their study results demonstrated that the anti-inflammatory activity of these extracts is related to their inhibition of cyclooxygenase enzymes, following the inhibition of prostaglandin synthesis. Singh et al. [202] examined the anti-inflammatory activity of methanol-aqeuous fractions (TAF) of B. prionitis on different acute and chronic animal test models. They observed that the iridoid-enriched fraction demonstrated activity against carrageenan-, histamine-, and dextran-induced inflammation models. Ibuprofen served as a standard for authenticity of the experiment. Marked inhibitory effect was exhibited by TAF in a dose-dependent manner on carrageenan-induced edema (normal rats), with the $\mathrm{ED}_{50}$ values being 89.70 and $143.51 \mathrm{mg} / \mathrm{kg}(11.93-44.56 \%)$ in adrenalectomized rats. Ibuprofen exhibited inhibition with a value of $54.03 \pm 2.51 \%$. The oral administration of TAF inhibited histamine- and dextran-induced edema, with the ED $\mathrm{ED}_{50}$ values being $333.52 \mathrm{mg} / \mathrm{kg}(12.16-36.14 \%)$ and $467.19 \mathrm{mg} / \mathrm{kg}$ (12.35-34.05\%), respectively. Additionally, the standard drug displayed inhibition with a value of $41.23 \pm 2.55 \%$. Therefore, the tested extract displayed promising anti-inflammatory activity when compared to the standard drug. 
Table 5. Anti-inflammatory activities of extracts, fractions and isolated compounds from species within Barleria.

\begin{tabular}{|c|c|c|c|c|c|}
\hline $\begin{array}{l}\text { Plant } \\
\text { Species }\end{array}$ & Plant Part & Extract & $\begin{array}{l}\text { Anti-Inflammatory } \\
\text { Activity/Assays/Model }\end{array}$ & Agent Dosage & Reference \\
\hline B. albostellata & $\begin{array}{l}\text { Leaves and } \\
\text { stems }\end{array}$ & $\begin{array}{l}\text { Petroleum ether, } \\
\text { dichloromethane, } \\
\text { ethanol }\end{array}$ & COX-1, COX-2 & $0.25 \mu \mathrm{g} / \mu \mathrm{L}$ & {$[66]$} \\
\hline \multirow{2}{*}{ B. cristata } & \multirow{2}{*}{ Leaves } & Water & $\begin{array}{l}\text { CIO in rat paws, prostaglandins } \\
\text { inhibitory activity, and acetic acid } \\
\text { induced capillary permeability } \\
\text { in mice. }\end{array}$ & $500 \mathrm{mg} / \mathrm{kg}$ & [203] \\
\hline & & Methanol & $\begin{array}{l}\text { Inhibited oedema produced by } \\
\text { histamine and serotonin in rats. } \\
\text { Reduction in the increased peritoneal } \\
\text { vascular permeability in mice }\end{array}$ & $500 \mathrm{mg} / \mathrm{kg}$ & [204] \\
\hline B. greenii & $\begin{array}{l}\text { Stems and } \\
\text { roots }\end{array}$ & $\begin{array}{l}\text { Petroleum ether, } \\
\text { dichloromethane, } \\
\text { ethanol }\end{array}$ & COX-1, COX-2 & $0.25 \mu \mathrm{g} / \mu \mathrm{L}$ & [66] \\
\hline \multirow{3}{*}{ B. lupulina } & Aerial & Water & $\begin{array}{l}\text { Activated the Nrf2 cell defense } \\
\text { pathway in human dermal } \\
\text { microvascular endothelial cells }\end{array}$ & - & [205] \\
\hline & Aerial & Methanol & $\begin{array}{l}\text { Acute and sub-acute inflammation } \\
\text { models of albino rats. }\end{array}$ & $300 \mathrm{mg} / \mathrm{kg}$ & [63] \\
\hline & Whole & Methanol, acetone & $\begin{array}{l}\text { CIO in rat paws and ethyl } \\
\text { phenylpropiolate-induced ear } \\
\text { oedema in rats. }\end{array}$ & 50-200 mg/kg & [206] \\
\hline B. montana & Leaves & Ethanol & $\begin{array}{l}\text { Formalin induced inflammation in } \\
\text { male albino wistar rats. }\end{array}$ & $300 \mathrm{mg} / \mathrm{kg}$ & [207] \\
\hline \multirow{4}{*}{ B. prionitis } & $\begin{array}{l}\text { Leaves, stems } \\
\text { and roots }\end{array}$ & $\begin{array}{l}\text { Petroleum ether, } \\
\text { dichloromethane, } \\
\text { ethanol }\end{array}$ & COX-1, COX-2 assays & $0.25 \mu \mathrm{g} / \mu \mathrm{L}$ & [66] \\
\hline & Whole & $\begin{array}{l}\text { Methanol-aqueous } \\
\text { fractions (TAF) }\end{array}$ & $\begin{array}{l}\mathrm{CIO} \text { in adrenalectomised rats, activity } \\
\text { in acute inflammation induced by } \\
\text { carrageenan, histamine and dextran } \\
\text { in rats }\end{array}$ & $100 \mathrm{mg} / \mathrm{kg}$ & [202] \\
\hline & Roots & Water fractions & $\mathrm{CIO}$ in rat paw model & $400 \mathrm{mg} / \mathrm{kg}$ & [208] \\
\hline & Aerial & $\begin{array}{l}\text { Shanzhiside } \\
\text { methylester, 8-O-acetyl } \\
\text { shanzhiside methyl } \\
\text { ester, iridoid } \\
\text { glycosides, } \\
\text { monoterpenoidal } \\
\text { fraction }\end{array}$ & $\begin{array}{l}\text { Stimulated rat neutrophils by } \\
\text { inhibiting MPO, elastase and MMP-9 } \\
\text { enzymes }\end{array}$ & $10 \mu \mathrm{g} / \mathrm{mL}$ & [209] \\
\hline
\end{tabular}

Cyclooxygenase (COX); Carrageenan-induced oedema (CIO); Nuclear factor erythroid 2-related factor 2 (Nrf2); Matrix Metalloproteinase-9 (MMP-9); Myeloperoxidase (MPO).

\subsection{Anticancer Activity}

Worldwide, cancer has been considered as the most critical disease in humans due to its high morbidity and mortality rates [210]. Radiotherapy, surgery, and chemotherapyare the primary therapies used to treat cancer. Although these therapies have saved the lives of several patients with cancer, the severe side effects and the high relapse rates have rendered them only moderately effective to control and in certain cases cure cancers. Therefore, there is an urgent need to develop more diverse and effective therapies from several sources [210]. Compared with synthetic chemotherapeutic drugs, natural chemicals derived 
from plants are relatively less toxic and possess high target specificity. Therefore, the potential usage of medicinal plants as anticancer drugs is important. In this regard, Barleria has demonstrated significant potential for anticancer activity, with several studies reporting the potent activity of extracts and isolated compounds against tumor cell lines (Table 6). In addition to $B$. prionitis, B. cristata and B. grandiflora have been frequently reported to exhibit potent anticancer activities (Table 6). El-Halawany et al. [211] examined the anticancer effects of phenolic compounds (verbascoside, isoverbascoside, dimethoxyverbascoside, $p$ hydroxybenzoic acid, and apigenin-7-O-glucoside) isolated from B. cristata. They found that preliminary treatment of Hepa-1c1c7 cells with $3.125 \mu \mathrm{M}$ of the tested isolated compounds inhibited the cytotoxic effect caused by menadione. Sulforaphane $(5 \mu \mathrm{M})$ served as the positive vehicle control. Among the tested compounds, the best results were observed for isoverbascoside, which potently induced the activity of the enzyme in a dose-dependent manner. Isoverbascoside exhibited the strongest effect in protecting Hepa-1c1c7 cells against the toxicity of menadione (quinone substrate for NQO1), causing an 8.8-fold induction of NQO1 activity at $25 \mu \mathrm{M}$ (compared with vehicle control activity level). The anticancer activity of the various phenolic compounds and controls used in this study is lacking statistical analyses, this may be a limitation which should be further explored. In addition, Manglani et al. [212] evaluated the anticancer activity of the leaf extracts of B. grandiflora on various normal and cancerous cell lines such as human lung cancer cells (A-549), Dalton's lymphoma ascites (DLA tumor cells), and African green monkey kidney (Vero) normal cells. Standard drug 5-Flurouracil (20 mg/ $\mathrm{kg}$ ) was the positive control in this study. They found that alcoholic leaf extracts exhibited cytotoxic effects against A-549 ( $\mathrm{IC}_{50}$ values (alcoholic extract $143.4 \mu \mathrm{g} / \mathrm{mL}$, aqueous extract $210.8 \mu \mathrm{g} / \mathrm{mL}$ ) and DLA ( IC $_{50}$ values (alcoholic extract $137.2 \mu \mathrm{g} / \mathrm{mL}$, aqueous extract $217.8 \mu \mathrm{g} / \mathrm{mL}$ ). The anti tumor activity of the alcoholic extract against DLA tumor bearing mice was assessed in vivo. The tumor volume, and viable cell count were significantly $(p<0.01)$ increased and non viable cell count had significantly $(p<0.01)$ declined in DLA control animals, when compared with normal control animals. The administration of the alcoholic extract in vivo, at 200 and $400 \mathrm{mg} / \mathrm{kg}$ significantly $(p<0.01)$ decreased the tumor volume and viable cell count. Overall, the alcoholic extract was potent to the Vero cell line, witha $\mathrm{IC}_{50}$ value of $148.7 \mu \mathrm{g} / \mathrm{mL}$, while the aqueous was less potent, with a $\mathrm{IC}_{50}$ value of $52.6 \mu \mathrm{g} / \mathrm{mL}$. Their study showed that the alcoholic extracts were less toxic to human cells and exhibited significant in vitro and in vivo antitumor activity against DLA cells.

Table 6. Anticancer activities of extracts and isolated compounds from species within Barleria.

\begin{tabular}{|c|c|c|c|c|c|}
\hline Plant Species & Plant Part & Extract/Compounds & Assays/Cell Lines & Agent Dosage & Reference \\
\hline \multirow{2}{*}{ B. cristata } & Aerial & Isoverbascoside & $\begin{array}{l}\text { NQO1 assay, murine hepatoma cell line } \\
\text { Hepa-1c1c7 }\end{array}$ & $3.125 \mu \mathrm{M}$ & [211] \\
\hline & $\begin{array}{l}\text { Leaves and } \\
\text { bark }\end{array}$ & Methanol & $\begin{array}{l}\text { Brine shrimp lethality assay, brine } \\
\text { shrimp cysts }\end{array}$ & $200 \mu \mathrm{g} / \mathrm{mL}$ & [146] \\
\hline B. gibsoni & Leaves & $\begin{array}{l}\text { Petroleum ether, } \\
\text { chloroform }\end{array}$ & $\begin{array}{l}\text { SRB assay, MDA, MB } 4355 \text { (Human breast } \\
\text { cancer) and Hep G2 (Liver cancer cell line) }\end{array}$ & $50 \mu \mathrm{g} / \mathrm{mL}$ & [213] \\
\hline \multirow{2}{*}{ B. grandiflora } & \multirow{2}{*}{ Leaves } & Alcoholic & $\begin{array}{l}\text { A-549 (human lung cancer) cells, DLA } \\
\text { tumour cells and Vero (African green } \\
\text { monkey kidney) normal cells }\end{array}$ & $300 \mu \mathrm{g} / \mathrm{mL}$ & [212] \\
\hline & & Ethanol & $\begin{array}{l}\text { MTT assay; Human gingival fibroblast cell } \\
\text { lines, human dermal fibroblast cell lines }\end{array}$ & $1000 \mu \mathrm{g} / \mathrm{mL}$ & [173] \\
\hline \multirow{2}{*}{ B. lupulina } & \multirow{2}{*}{ Leaves } & Ethanol & MTT assay; cancerous THP- 1 cell lines & $100 \mu \mathrm{g} / \mathrm{mL}$ & [214] \\
\hline & & Ethanol & MTT assay; HepG2 cells & $1000 \mu \mathrm{g} / \mathrm{mL}$ & [174] \\
\hline
\end{tabular}


Table 6. Cont.

\begin{tabular}{|c|c|c|c|c|c|}
\hline Plant Species & Plant Part & Extract/Compounds & Assays/Cell Lines & Agent Dosage & Reference \\
\hline \multirow[b]{2}{*}{ B. prionitis } & \multirow[b]{2}{*}{ Leaves } & Ethanol & $\begin{array}{l}\text { MTT assay; Human gingival fibroblast cell } \\
\text { lines, human dermal fibroblast cell lines, }\end{array}$ & $1000 \mu \mathrm{g} / \mathrm{mL}$ & [173] \\
\hline & & Ethanol & $\begin{array}{l}\text { SRB assay, breast (MCF-7), } \\
\text { colon (DLD-1), lung } \\
\text { (A549), breast metastatic (MDMAMB-468), } \\
\text { lung metastatic (NCIH358) and colon } \\
\text { metastatic (SW620) }\end{array}$ & $100 \mu \mathrm{g} / \mathrm{mL}$ & [215] \\
\hline B. strigosa & Leaves & Butanol & $\begin{array}{l}\text { MTT colorimetric assay, Human } \\
\text { hepatocellular carcinoma (HepG2), human } \\
\text { breast adenocarcinoma (MCF7), human } \\
\text { oral epidermoid carcinoma (KB), human } \\
\text { colon adenocarcinoma (HT29), murine } \\
\text { lymphocytic leukemia (P388), human } \\
\text { cervical carcinoma (HeLa) as well as two } \\
\text { normal cell lines including African green } \\
\text { monkey kidney (Vero) and mouse } \\
\text { subcutaneous connective tissue (L929) }\end{array}$ & $2000 \mu \mathrm{g} / \mathrm{mL}$ & [186] \\
\hline
\end{tabular}

MTT-(3-(4, 5-dimethylthiazolyl-2)-2, 5-diphenyltetrazolium bromide); DLA-Dalton's lymphoma Ascites; NQO1- (NAD(P)H dehydrogenase [quinone] 1); SRB-Sulphorhodamine B.

\subsection{Antidiabetic Activity}

Based on folkloric claims, people with diabetes have been treated orally with various medicinal plants or their extracts since ancient times [216]. Hypoglycemic synthetic agents can produce severe side effects, including liver and kidney function disturbances and hematological coma [217]. Therefore, the search for more safe and effective antidiabetic agents in plants has continued to be a critical area for research. Barleria species have also demonstrated antidiabetic activities as shown in Table 7. According to Singh et al. [218], oral administration of ethanolic seed extract $(200 \mathrm{mg} / \mathrm{kg})$ from B. cristata for 7 days decreased blood glucose levels in a model of alloxan-induced diabetes in rats. The control group received normal saline only. Statistical analysis is lacking in this study. Therefore, further studies should evaluate the active compounds responsible for the anti-diabetic displayed in B. cristata. Furthermore, Vasanth et al. [147] investigated the ethanol and petroleum ether leaf extracts of B. cristata for their antidiabetic activity and found that both extracts exhibited dose-dependent increases in the inhibitory activities of $\alpha$-glucosidase (inhibition: ethanol extract $47 \%$ and petroleum ether extract $44 \%$ ) and $\alpha$-amylase (inhibition: ethanol extract $67 \%$ and petroleum ether extract $61 \%$ ) at a concentration of $100 \mu \mathrm{L}$. Butylated hydroxytoluene served as the positive control. Overall, the best results were obtained with ethanol extracts that demonstrated the maximum in vitro antidiabetic activity compared with petroleum ether extract. It is recommended that further investigations should evaluate other compounds as positive controls (i.e., acarbose). Reema and Pradeep [219] reported about the antidiabetic properties of $B$. prionitis. The control group received distilled water. They observed a reduction in glycosylated hemoglobin $(p<0.01)$ and blood glucose $(p<0.01)$ levels in alloxan-induced diabetic rats treated with the ethanolic leaf extract. A further observation in their study was an increase in liver glycogen and serum insulin levels but a decrease in body weight. In experimental animals, the root ethanolic extract ( $200 \mathrm{mg} / \mathrm{dL}$ ) exhibited a moderate but nonsignificant antidiabetic activity. Further studies should elucidate its mechanism in detail. The above-described results thus confirm the antidiabetic potential of the various species of Barleria, however further studies should be conducted to for further validation. 
Table 7. Antidiabetic activities of extracts and fractions from species within Barleria.

\begin{tabular}{|c|c|c|c|c|c|}
\hline $\begin{array}{l}\text { Plant } \\
\text { Species }\end{array}$ & Plant Part & Extract & Antdiabetic Activity/Assays/Models & Agent Dosage & Reference \\
\hline B. bispinosa & Aerial & Methanol & $\begin{array}{l}\text { Male Wister rats, Streptozotocin induced } \\
\text { diabetic rats }\end{array}$ & $500 \mathrm{mg} / \mathrm{kg}$ & [220] \\
\hline \multirow[b]{2}{*}{ B. cristata } & Seeds & Ethanol & Wistar rats, alloxan-induced diabetic rats & $200 \mathrm{mg} / \mathrm{kg}$ & [218] \\
\hline & $\begin{array}{l}\text { Leaves and } \\
\text { roots }\end{array}$ & $\begin{array}{l}\text { Ethanol and } \\
\text { petroleum } \\
\text { ether }\end{array}$ & $\begin{array}{l}\text { Inhibition of alpha-amylase enzyme assay, } \\
\text { Inhibition of alpha-glucosidase } \\
\text { enzyme assay }\end{array}$ & - & [147] \\
\hline B. lupulina & Aerial & Methanol & Male Wister rats, Streptozotocin-diabetic rats & $300 \mathrm{mg} / \mathrm{kg}$ & [61] \\
\hline B. montana & Aerial & Methanol & $\begin{array}{l}\text { Wistar albino rats; Streptozotocin induced } \\
\text { diabetic rats }\end{array}$ & $400 \mathrm{mg} / \mathrm{kg}$ & {$[221]$} \\
\hline \multirow{3}{*}{ B. noctiflora } & Aerial & Ethyl acetate & $\begin{array}{l}\text { Wister rats, Streptozotocin induced type- } 2 \\
\text { diabetes in rats }\end{array}$ & $400 \mathrm{mg} / \mathrm{kg}$ & [222] \\
\hline & Whole & Ethanol & $\begin{array}{l}\text { In-vitro anti-diabetic activity was } \\
\text { determined by inhibition of } \alpha \text {-glucosidase } \\
\text { and inhibition of } \alpha \text {-amylase studies }\end{array}$ & $500 \mu \mathrm{g} / \mathrm{mL}$ & [223] \\
\hline & Aerial & Ethyl acetate & $\begin{array}{l}\text { Wister rats, Streptozotocin induced } \\
\text { diabetic rats }\end{array}$ & - & {$[224]$} \\
\hline \multirow{2}{*}{ B. prionitis } & $\begin{array}{l}\text { Leaves and } \\
\text { roots }\end{array}$ & Ethanol & $\begin{array}{l}\text { Adult Albino rats, alloxan-induced } \\
\text { diabetic rats }\end{array}$ & $200 \mathrm{mg} / \mathrm{kg}$ & [219] \\
\hline & $\begin{array}{l}\text { Leaves, stems } \\
\text { and roots }\end{array}$ & Alcohol & $\begin{array}{l}\text { Albino rats, alloxan-induced } \\
\text { hyperglycemic rats }\end{array}$ & $200 \mathrm{mg} / \mathrm{kg}$ & [225] \\
\hline
\end{tabular}

\subsection{Antiulcer Activity}

Gastric hyperacidity is a common problem that affects millions of individuals worldwide due to an imbalance between protective and aggressive factors [226]. Peptic ulcers are generally treated using proton pump inhibitors, $\mathrm{H}_{2}$ receptor antagonists, and antimuscarinics. However, the majority of these agents produce adverse effects such as impotence, arrhythmia, gynecomastia, hypersensitivity, and hematopoietic disorders [227]. Therefore, it is crucial to explore plants containing natural antiulcer and antioxidant compounds that can be used as safer treatment alternatives with less side effects. Several studies have demonstrated the antiulcer activity of extracts of Barleria (Table 8). Kumar and Singh [52] investigated the antiulcer activity of the methanolic leaf extracts of B. prionitis. They reported a statistically significant reduction $(p=0.05)$ of ulcer index in the treated animals in comparison with control groups in both models. Ranitidine $(50 \mathrm{mg} / \mathrm{kg})$ served as the positive control in this study exhibited significant protection, $p<0.01$. Substantial changes were observed only in the total acidity at a dose of $500 \mathrm{mg} / \mathrm{kg}$, and changes were significant in the levels of aspartate aminotransferase (AST) and alanine aminotransferase (ALT) at both doses in the ethanol-induced gastric ulcer model. Further studies are required to isolate compounds from these extracts and elucidate their mechanism of action. Jaiswal et al. [228] examined the gastroprotective effect of iridoid fractions obtained from the leaves of $B$. prionitis against various gastric ulcer models in rats. They observed that the fractions exhibited a dose-dependent ulcer-protective effect in ulcer models induced by pylorus ligation (PL) (18.67-66.26\% protection), aspirin (24.65-63.25\% protection), cold-restraint stress (CRS) (20.77-59.42\% protection), and ethanol (16.93-77.04\% protection). Ranitidine and sucralfate were used as the positive control.The iridoid fractions derived from B. prionitis demonstrated antiulcerogenic properties $\left(200 \mathrm{mg} \cdot \mathrm{kg}^{-1}\right)$ by decreasing the acid-pepsin secretions in rat models of gastric ulcer [228]. The fractions reduced the ulcer index by significantly decreasing the lipid peroxidation product $(p<0.01-0.001)$ in comparison to the control, and superoxide dismutase activity $(p<0.01-0.001)$ and increasing the catalase activity in the CRS-induced model. 
Table 8. Antiulcer activities of extracts and fractions from species within Barleria.

\begin{tabular}{|c|c|c|c|c|c|}
\hline $\begin{array}{l}\text { Plant } \\
\text { Species }\end{array}$ & Plant Part & Extract & $\begin{array}{l}\text { Antiulcer Activity/Gastric Cytoprotective } \\
\text { Activity/Models }\end{array}$ & Agent Dosage & Reference \\
\hline B. buxifolia & Whole & Methanol & Wistar rats, PL and aspirin induced ulcers & $400 \mathrm{mg} / \mathrm{kg}$ & [229] \\
\hline B. gibsoni & Leaves & Ethanol & Wistar rats, PL-induced ulcer models & $500 \mathrm{mg} / \mathrm{kg}$ & [53] \\
\hline B. lupulina & Aerial & Methanol & $\begin{array}{l}\text { Albino (Wistar) rats, PL ulceration in rats, } \\
\text { stress-induced ulceration, drug-induced gastric } \\
\text { ulcer in rats, duodenal ulcers in rats. }\end{array}$ & $200 \mathrm{mg} / \mathrm{kg}$ & [62] \\
\hline \multirow{4}{*}{ B. prionitis } & \multirow{4}{*}{ Leaves } & Methanol & $\begin{array}{l}\text { Wistar rats; ethanol induced gastric mucosal } \\
\text { lesions, indomethacin induced ulcer models }\end{array}$ & $500 \mathrm{mg} / \mathrm{kg}$ & [52] \\
\hline & & Ethanol & $\begin{array}{l}\text { Male Sprague-Dawley rats and female Swiss } \\
\text { albino mice; PL- induced ulcers, aspirin- induced } \\
\text { ulcers, CRS-induced ulcers, ethanol-induced ulcer }\end{array}$ & $200 \mathrm{mg} / \mathrm{kg}$ & [228] \\
\hline & & Methanol & Ethanol and Indomethacin Induced ulcer models & $500 \mathrm{mg} / \mathrm{kg}$ & [230] \\
\hline & & Chloroform & $\begin{array}{l}\text { Rodent experimental models (indomethacin and } \\
\text { pylorus ligation) }\end{array}$ & $250 \mathrm{mg} / \mathrm{kg}$ & [52] \\
\hline
\end{tabular}

CRS—cold-restraint stress; PL—Pylorus ligated.

\subsection{Hepatoprotective Activity}

Liver diseases (acute and chronic) are a global concern [231], and their treatment is difficult to achieve because none of the available drugs have been effective in stimulating liver function or aiding the liver to regenerate hepatic cells [232,233]. In addition, hepatotoxic chemicals cause damage to liver cells by accelerating lipid peroxidation and other oxidative injuries [234-238]. Hence, due to increasing incidences of chemically induced hepatotoxicity, there is a demand for safe protective agents [233]. Conseqeuntly, it is essential to explore alternative drugs from plant sources that are safe and efficient in treating liver diseases. Therefore, several medicinal plants, especially within the genus Barleria, have been screened for hepatoprotective activity by various researchers (Table 9). For instance, Balaji et al. [239] investigated the hepatoprotective activity of the ethanolic leaf extracts of B. cristata against $\mathrm{CCl}_{4}(0.7 \mathrm{~mL} / \mathrm{kg}$, i.p)-induced hepatic damage in Wistar albino rats (at dose levels of 100-200 mg/kg). Silymarin was administered as the positive control in this study. The ethanolic extract significantly $(p<0.001)$ decreased the serum levels of specific liver enzymes such as alanine aminotransferase, aspartate aminotransferase, and alkaline phosphatase and total protein, total bilirubin, triglyceride, and cholesterol levels. They used a known hepatoprotective drug, silymarin $(25 \mathrm{mg} / \mathrm{kg})$, for comparison that displayed significant activity $(p<0.001)$. The ethanolic extract did not cause any mortality in the Wistar rats (up to a dose level of $200 \mathrm{mg} / \mathrm{kg}$ ). Overall, their study results indicated that the ethanolic extract exhibited hepatoprotective properties, which may be due to the presence of flavonoids and alkaloids [239].

Singh et al. [240] also evaluated the iridoid-enriched fractions obtained from the ethanol-aqueous leaf and stem extracts of B. prionitis for hepatoprotective activity in Charles Foster rats and Swiss albino mice. These fractions exhibited hepatoprotective activity in several chronic and acute animal test models. Silymarin; Liv-52 and stimuliv were used as positive controls to compare the results. After a single dose of drug administration, the oral $\mathrm{LD}_{50}$ value was found to be $>3000 \mathrm{mg} / \mathrm{kg}$, with no signs of deformities or mortality (for a duration of 15 days). However, the intraperitoneal LD $_{50}$ was found to be $2530 \pm 87 \mathrm{mg} / \mathrm{kg}$ in mice. Although the maximum tolerance dose is high, the safety evaluation of animal models displayed no signs of abnormalities or any mortality. Statistical analysis showed a significant difference between control and the drug treated groups. The extracts provided significant hepatoprotection against hepatotoxicity induced by galactosamine, carbon tetrachloride, and paracetamol. Overall, their study reported significant and concentration-dependent hepatoprotective activity of the iridoid-enriched 
fractions, as most of the altered hepatic parameters in experimental rodents (liver damage) were reversed. Further studies should be conducted to assess the extracts safety. Hence, extracts derived from Barleria have hepatoprotective properties that can serve as an effective treatment for acute hepatic diseases.

Table 9. Hepatoprotective activities of extracts and fractions from species within Barleria.

\begin{tabular}{|c|c|c|c|c|c|}
\hline $\begin{array}{l}\text { Plant } \\
\text { Species }\end{array}$ & Plant Part & Extract & Hepatoprotective Activity/ASSAYS/Models & $\begin{array}{l}\text { Agent Dosage } \\
(\mathrm{mg} / \mathrm{kg})\end{array}$ & Reference \\
\hline B. cristata & Leaves & Ethanol & $\begin{array}{l}\text { Wistar albino rats, } \mathrm{CCl}_{4} \text { induced hepatic damage } \\
\text { in rats }\end{array}$ & 200 & [238] \\
\hline B. cuspidata & Leaves & Methanol & $\begin{array}{l}\text { Wistar albino rats, } \mathrm{CCl}_{4} \text { induced hepatotoxicity } \\
\text { in rats }\end{array}$ & 400 & [241] \\
\hline B. gibsoni & Aerial & $\begin{array}{l}\text { Aqueous } \\
\text { alcoholic }\end{array}$ & $\begin{array}{l}\text { Wistar albino rats; inducing agent Paracetamol in } \\
\text { Carboxy methyl cellulose }\end{array}$ & 400 & [242] \\
\hline \multirow[t]{2}{*}{ B. montana } & Leaves & Methanol & $\begin{array}{l}\text { Wistar albino rats; ethanol-induced rat } \\
\text { hepatic injury }\end{array}$ & 500 & [243] \\
\hline & Aerial & Methanol & $\mathrm{CCl}_{4}$ induced hepatotoxicity on rats & 800 & [178] \\
\hline B. prionitis & $\begin{array}{l}\text { Leaves and } \\
\text { stems }\end{array}$ & $\begin{array}{l}\text { Fractions } \\
\text { from } \\
\text { ethanol- } \\
\text { aqueous }\end{array}$ & $\begin{array}{l}\text { Charles Foster rats, Swiss albino mice; acute and } \\
\text { chronic animal test models, } \mathrm{CCl}_{4} \text { toxicity, } \\
\text { cetaminophen (APAP) toxicity, D-GalN induced } \\
\text { hepatotoxicity }\end{array}$ & 200 & {$[240]$} \\
\hline
\end{tabular}

\subsection{Analgesic Activity}

Unbearable and long-term pain is one of the primary causes for poor quality of life, and therefore, several researchers are investigating the mechanisms and causes of pain and are exploring novel drugs in plants to reduce pain with less to no side effects. Although analgesic drugs are available and efficient in reducing pain, their repetitive application can cause several side effects such as tolerance and physical dependence [244,245]. Regarding the genus Barleria, the literature reports only one study conducted by Begum et al. [246], who investigated the effects of ethanol, chloroform, and petroleum ether extracts of the aerial parts of B. prionitis in Swiss albino mice at doses of 200 and $400 \mathrm{mg} / \mathrm{kg}$. Overall, their study indicated that all the three extracts demonstrated significant analgesic effects in mice, with inhibition proportions of $30.36 \%, 59.40 \%$, and $33.70 \%$ when tested at $400 \mathrm{mg} / \mathrm{kg}$.

\subsection{Antiamoebic Activity}

A common intestinal infection occurring in humans in developing countries is amoebiasis, which is caused by the protozoan parasite Entamoeba histolytica. Trophozoites of E. histolytica invade the intestinal mucosa, resulting in dysentery, and thereafter sporadically migrate to the liver, triggering abscesses $[247,248]$. Although the drugs used in the treatment of amoebiasis are effective, they induce various side effects such as nausea, stomatitis, gastrointestinal discomfort, and vomiting [249-253]. Therefore, it is essential to identify new compounds in plants possessing antiamoebic activity that are safe for human usage. Till date, only one study has been conducted on the antiamoebic activity of a species of Barleria. Sawangiaroen et al. [254] evaluated the antiamoebic activities of the chloroform leaf and stem extracts of B. lupulina at a concentration of $1000 \mu \mathrm{g} / \mathrm{mL}$ against the E. histolytica strain (HM1:IMSS). Metronidazole served as the positive control. They observed that the chloroform extract derived from B. lupulina stem exhibited the best antiamoebic activity $\left(\mathrm{IC}_{50} 78.5 \mu \mathrm{g} / \mathrm{mL}\right.$ ) against E. histolytica then when compared to the leaf extract. The stem extract was classified as active, with an $\mathrm{IC}_{50}$ value of $<100 \mu \mathrm{g} / \mathrm{mL}$ [254]. The $\mathrm{IC}_{50}$ of a standard drug, metronidazole, was $1.1 \mu \mathrm{g} / \mathrm{mL}$. 


\subsection{Antihelminthic Activity}

Helminths are parasitic worms that are infectious to humans in developing countries [255]. These worms reside in the gastrointestinal tract and can burrow into the liver and other organs. Infected individuals excrete helminth eggs in their fecal matter, causing the contamination of soil in areas with poor sanitation [256]. The drugs used to treat these infections have common side effects such as vomiting, nausea, abdominal pain, allergic reactions, expulsion of ascaris from mouth or nose, body ache, and fever [257]. Consequently, the search for plants exhibiting antihelminthic activity with no side effects is critical. There is a scarcity of research on the genus Barleria exploring the antihelmintic activity of its plant extracts; Table 10 displays the few studies investigating this activity reported in the literature. Chander et al. [258] examined the antihelmintic activity of B. buxifolia water and ethanolic leaf extracts against Pheretima posthuman worms. They found that the ethanolic extract at $100 \mathrm{mg} / \mathrm{mL}$ produced a significant effect $(p<0.001)$ compared with the water extract. The water extract caused a dose-dependent paralysis that varied from loss of motility, loss of response to stimuli, and ultimately progressed to death. In the P. posthuma worms, the ethanolic extract took $37.75 \pm 2.06 \mathrm{~min}$ for paralysis and $89.00 \pm 1.82 \mathrm{~min}$ for death, whereas the duration for the water extract was $64.00 \pm 2.16 \mathrm{~min}$ for paralysis and $150.50 \pm 2.64 \mathrm{~min}$ for death. Chavan et al. [259] also evaluated the antihelmintic activity (paralysis and time of death) of whole water and ethanolic extracts of B. prionitis against P. posthuma. They reported that both water and ethanolic extracts significantly demonstrated paralysis $(p<0.01)$ in worms at lower doses $(50,75$, and $100 \mathrm{mg} / \mathrm{mL})$ and resulted in death at a high concentration of $100 \mathrm{mg} / \mathrm{mL}$ compared with albenadazole (standard).

Table 10. Anthelmintic activities of extracts from species within Barleria.

\begin{tabular}{llllcc}
\hline $\begin{array}{l}\text { Plant } \\
\text { Species }\end{array}$ & $\begin{array}{l}\text { Plant } \\
\text { Part }\end{array}$ & Extract & $\begin{array}{l}\text { Anthelmintic Activ- } \\
\text { ity/Assays/Models }\end{array}$ & $\begin{array}{c}\text { Agent Dosage } \\
\text { (mg/mL) }\end{array}$ & Reference \\
\hline B. buxifolia & Leaves & Ethanol & IAW P. posthuma & 100 & {$[258]$} \\
\hline B. gibsoni & Leaves & Water, ethanol & IAW P. posthuma & 15 & {$[260]$} \\
\hline \multirow{2}{*}{$\begin{array}{l}\text { B. prionitis } \\
\text { Whole }\end{array}$} & Water, ethanol & IAW P. posthuma & 100 & {$[259]$} \\
\cline { 2 - 5 } & & Water, ethanol & IAW P. posthuma & 100 & {$[261]$} \\
\hline
\end{tabular}

IAW-Indian adult worm; Pheretima posthuma.

\subsection{Antiarthritic Activity}

Rheumatoid arthritis is an autoimmune disease characterized by synovial membrane inflammation, pain, peripheral joint inflammation, destruction of articular tissue, and joint movement restriction [262-264]. This disease can affect an individual's ability to perform daily tasks and causes premature death [265]. Irrespective of the progress made in the management of this disease, the treatments fail to generate long-term benefits, thus resulting in adverse effects such as renal morbidity, gastrointestinal ulcers, hematological toxicity, and cardiovascular complications $[266,267]$. This necessitates identifying alternative methods that cause less to no adverse effects. Therefore, it is essential to explore drugs from plant sources that exhibit antiarthritic activity. Table 11 summarizes the reported antiarthritic properties of various extracts and fractions of Barleria. A study conducted by Choudhary et al. [268] investigated the antiarthritic potential of ethyl acetate fractions from the leaves of B. prionitis against Freund's complete adjuvant-induced chronic arthritis and formaldehydeinduced acute nonimmunological arthritis in rats. They reported significant inhibition of edema in Sprague Dawley rats in acute and chronic models. Diclofenac sodium served as the positive control in this study. The fraction used at a dose of $250 \mathrm{mg} / \mathrm{kg}$ exhibited potent and significant $(p \leq 0.05-0.01)$ inhibition of paw edema. Ethyl acetate fraction was found to decrease the histopathological changes induced by Freund's complete adjuvant. Further studies are required to carry out the isolation of active constituents of the fraction responsible for the above activity. Overall, their study results disclosed the potential use of 
B. prionitis fraction in protecting the synovial membrane through hematinic parameters, thus demonstrating promising antiarthritic activity.

Table 11. Antiarthritic activities of extracts and fractions from species within Barleria.

\begin{tabular}{|c|c|c|c|c|c|}
\hline $\begin{array}{l}\text { Plant } \\
\text { Species }\end{array}$ & Plant Part & Extract & Antiarthritic Activity/Assays/Models & $\begin{array}{l}\text { Agent Dosage } \\
(\mathrm{mg} / \mathrm{kg})\end{array}$ & Reference \\
\hline B. lupulina & Leaves & Methanol & $\begin{array}{l}\text { Albino male mice, female Sprague Dawley rats, } \\
\text { formalin-induced arthritis, adjuvant induced } \\
\text { arthritis, collagen type II-induced arthritis, } \\
\text { monosodium iodoacetate induced osteoarthritis }\end{array}$ & 600 & [269] \\
\hline \multirow[t]{2}{*}{ B. montana } & Leaves & Ethanol & $\begin{array}{l}\text { Male Albino Wistar rats, Complete Freund's } \\
\text { in vivo method in induced rats }\end{array}$ & 400 & [270] \\
\hline & Leaves & $\begin{array}{l}\text { Ethyl } \\
\text { acetate } \\
\text { fraction }\end{array}$ & $\begin{array}{l}\text { Sprague Dawley rats, formaldehyde induced } \\
\text { arthritis; FCA-induced arthritis rat model }\end{array}$ & 250 & [268] \\
\hline B. prionitis & Whole & Methanol & Complete Freund's induced rat model & 400 & [271] \\
\hline
\end{tabular}

\subsection{Antihypertensive Activity}

Hypertension, also defined as high blood pressure, is an ailment in which blood vessels persistently increase the blood pressure of an individual [272]. This ailment contributes to the burden of premature mortality, heart diseases, disability, stroke, and kidney failure. Although several conventional antihypertensive drugs are used for hypertension treatment, they have adverse side effects such as extreme tiredness, dizziness, cramps, dehydration, and abnormal heart rate [273]. Therefore, researchers are focusing on herbal drugs as a source of treatment. Moreover, it is important to examine plants and their derivatives for antihypertensive activity. In this context, the methanolic leaf extracts of $B$. prionitis at doses of 200 and $400 \mathrm{mg} / \mathrm{kg}$ were found to exhibit antihypertensive effects and displayed $103 \pm 2.54,1005 ; \pm, 274$, and $105.5 \pm 2.35 \mathrm{~mm} \mathrm{Hg}$ of diastolic blood pressure and $136.5 \pm 2.51,146 \pm 2.21$, and $143 \pm 3.11 \mathrm{~mm} \mathrm{Hg}$ of systolic blood pressure after a 6-week treatment period [274].

\subsection{Antiviral Activity}

Viral infections are the primary causes of diseases because of their complexity and diversity. This makes it difficult to counteract their diffusion and effects, which often result in pandemic events [275]. Moreover, the increased frequency of global travel, urbanization, and migration have rendered virus outbreaks a challenging issue for public health, specifically when antiviral therapies and vaccines are not available [276]. In addition, the unsuccessful rate of numerous conventional drugs against viral infections and the onset of viral resistances have resulted in a growing interest in plants for promising antiviral agents [277]. Yoosook et al. [58] analyzed the leaf extracts of B. lupulina for intracellular activities against HSV-2 and five clinical HSV-2 isolates. Acyclovir was used as a positive control for anti-HSV in this study. Their study results demonstrated that the extracts exhibited activity against all the five clinical HSV-2 isolates. Further studies should be conducted using different assays on clinical isolates and not only standard strains of the virus. Chen et al. [87] also reported about the isolation of iridoid glycosides (6-O-trans$p$-coumaroyl-8-O-acetylshanzhiside methyl ester and its cis isomer) from the methanolic extracts of $B$. prionitis, and these extracts were found to exhibit potent in vitro activity against the respiratory syncytial virus $\left(\mathrm{EC}_{50} 2.46 \mu \mathrm{g} / \mathrm{mL}, \mathrm{IC}_{50} 42.2 \mu \mathrm{g} / \mathrm{mL}\right.$ ) [54].

\subsection{Inhibition of Acetylcholinesterase Activity}

Acetylcholine is a neurotransmitter at all parasympathetic, preganglionic autonomic, and sympathetic postganglionic nerve endings, as well as at the neuromuscular junction 
and at some central nervous system synapses. Acetylcholinesterase (AchE) inhibitors comprise several compounds of diverse structures and have the ability to inhibit the acetylcholine neurotransmitter $[278,279]$. AchE inhibitors are the most common drugs used in the treatment of diseases such as Parkinson's, Alzheimer's, senile dementia, and ataxia [280]. However, drugs such as rivastigmine, galantamine, and donepezil have limitations for medical use due to their adverse side effects [281]. Therefore, it is necessary to explore the plant kingdom for drugs that may inhibit acetylcholinesterase. The various extracts and isolated compounds of Barleria with reported acetylcholinesterase inhibitory activity are summarized in Table 12.

Table 12. Acetylcholinesterase inhibition of extracts and isolated compounds from species within Barleria.

\begin{tabular}{|c|c|c|c|c|c|}
\hline $\begin{array}{l}\text { Plant } \\
\text { Species }\end{array}$ & Plant Part & Extract/Compound & $\begin{array}{l}\text { Inhibition of } \\
\text { Acetylcholinesterase/ }\end{array}$ & Agent Dosage & Reference \\
\hline $\begin{array}{l}\text { B. } \\
\text { albostellata }\end{array}$ & $\begin{array}{l}\text { Leaves, } \\
\text { stems and } \\
\text { roots }\end{array}$ & Methanol & $\begin{array}{l}\text { Microtitre plate assays based on the } \\
\text { colorimetric method; and using the } \\
\text { positive control galanthamine }\end{array}$ & $625 \mu \mathrm{g} / \mathrm{mL}$ & [98] \\
\hline B. greenii & $\begin{array}{l}\text { Leaves, } \\
\text { stems and } \\
\text { roots }\end{array}$ & Methanol & $\begin{array}{l}\text { Microtitre plate assays based on the } \\
\text { colorimetric method; and using the } \\
\text { positive control galanthamine }\end{array}$ & $625 \mu \mathrm{g} / \mathrm{mL}$ & [98] \\
\hline \multirow[b]{3}{*}{ B. prionitis } & $\begin{array}{l}\text { Leaves, } \\
\text { stems and } \\
\text { roots }\end{array}$ & Methanol & $\begin{array}{l}\text { Microtitre plate assays based on the } \\
\text { colorimetric method; and using the } \\
\text { positive control galanthamine }\end{array}$ & $625 \mu \mathrm{g} / \mathrm{mL}$ & [98] \\
\hline & \multirow[b]{2}{*}{ Aerial } & $\begin{array}{l}\text { 8-amino-7- } \\
\text { hydroxypipataline }\end{array}$ & $\begin{array}{l}\text { Modified Ellman's assay, } \\
\text { photometric method }\end{array}$ & - & [86] \\
\hline & & $\begin{array}{l}\text { 6-O-trans- } p \text {-coumaroyl-8-O- } \\
\text { actylshanzhiside methyl } \\
\text { ester, barlerin, } \\
\text { acetylbarlerin, } \\
\text { 7-methoydiderroside, } \\
\text { lupulinoside }\end{array}$ & Ellman's assay & - & [67] \\
\hline
\end{tabular}

Amoo et al. [98] evaluated the acetylcholinesterase inhibitory activity of the methanolic extract of B. prionitis and found that it exhibited a dose-dependent inhibition action. The positive control used in this study was galanthamine. The AChE inhibition activities by galanthamine at $0.5,1.0$ and $2 \mu \mathrm{M}$ were $49.24,59.81$ and $77.03 \%$, respectively. At a higher concentration of extract $(625 \mu \mathrm{g} / \mathrm{mL})$, the leaf and stem of B. prionitis demonstrated greater inhibitory activity than its root extract. Kosmulalage et al. [86] also reported about the isolation of various compounds from the ethanolic extract of B. prionitis and their potential in inhibiting acetylcholinesterase. Balarenone, along with lupeol, pipataline, and 13,14seco-stigmasta-5,14-diene-3- $\alpha$-ol, isolated from ethanolic extract demonstrated moderate inhibitory activity against AChE [86]. Three distinct derivatives of pipataline, viz., 8amino-7-hydroxypipataline, 7,8-epoxypipataline, and 7,8-dibromopipataline, were further synthesized to evaluate their inhibitory potential against acetylcholinesterase. Among the tested compounds, the best results were observed with 8-amino-7-hydroxypipataline, which exhibited significant acetylcholinesterase inhibitory activity with an $\mathrm{IC}_{50}$ value of $36.8 \mu \mathrm{M}$. Therefore, plant species within the genus Barleria demonstrate significant potential in inhibiting acetylcholinesterase activity.

\subsection{Toxicology/Safety of Extracts of Barleria}

Narmadha and Devaki [282] evaluated the acute toxicity and effective dose determination of the ethanolic leaf extract of B. cristata $\mathrm{L}$. in wistar albino rats. Based on their body weight $(250,500,1000$ and 2,000 mg/kg), the ethanolic leaf extract were administered orally as a single dose to rats. Results showed that the administration of the ethanolic leaf extract 
at all doses (up to $2000 \mathrm{mg} \mathrm{kg}$ ) did not produce any sign of acute toxicity or instant death in rats while tested during the period of observation. Singh et al. [240] evaluated the induced hepatotoxicity of the ethanol-water extract of the leaves and stems of B. prionitis in various experimental models, $\mathrm{CCl}_{4}, \mathrm{D}-\mathrm{GalN}$ and paracetamol. In the safety evaluation study the oral $\mathrm{LD}_{50}$ was found to be $>3000 \mathrm{mg} / \mathrm{kg}$, with no signs of mortality after a single dose of drug administration. Kumari et al. [42] determined the toxicity of the methanol leaf and stem extracts by selecting different concentration of doses administered to albino rat (\% mortality by using standard test). No mortality of albino rats $(200,400$ and $600 \mathrm{mg} / \mathrm{kg}$ body weight) was recorded in both treatments of extracts. There is a scarcity of information on the toxicology and safety of extracts of Barleria, thus further studies are required.

\section{Synthesis of Silver Nanoparticles from Plant Extracts of Species within Barleria}

Nanotechnology is an emerging field that focuses on the synthesis and application of small materials known as nanoparticles $(<100 \mathrm{~nm})$ [283-287]. The physical properties of nanoparticles such as their size, shape, morphology, and their large surface-area-to-volume ratio have optimized their activity in various fields such as chemistry, medicine, and agriculture [288-290]. Significant development has been made in the study of metal-derived nanomaterials for their therapeutic and biomedical applications [291]. The development of multiple drug-resistant microorganisms poses a worldwide threat to public health [292]. Inappropriate use of antibiotics allow microorganisms to develop mutations, thereby making them resistant to conventional biocides [285,292,293]. Treatment of diseases caused by drug-resistant pathogens can lead to increased rates of morbidity and mortality [294-296]. Therefore, there is a need for extensive research in nanotechnology for identifying an effective treatment against drug-resistant bacteria [297].

Synthesis of nanoparticles from plants has received considerable attention due to their efficient use as reducing and capping agents of metals and their broad range of pharmacological applications [298]. Plants are widely available and less toxic, making this technique environmentally friendly and cost effective [299,300]. Medicinal plants are an abundant source of biologically active compounds. It is assumed that the bioreduction of nanoparticles using plant extracts is merely due to the presence of phytochemicals such as flavones, organic acids, polyphenols, and quinones [301,302]. The most frequently used metal nanoparticle for synthesizing plant constituents is silver [303]. Silver nanoparticles (AgNPs) are extremely toxic to multidrug-resistant bacteria [304].

Table 13 summarizes the biological activities of synthesized AgNPs from various extracts of Barleria. Govindarajan and Benelli [305] examined the toxicity of AgNPs synthesized from $B$. cristata leaf extracts against the larvae of Aedes albopictus (LC 50 value $12.46 \mu \mathrm{g} / \mathrm{mL})$, Culex tritaeniorhynchus $\left(\mathrm{LC}_{50}\right.$ value $\left.13.49 \mu \mathrm{g} / \mathrm{mL}\right)$, and Anopheles subpictus ( $\mathrm{LC}_{50}$ value $15.01 \mu \mathrm{g} / \mathrm{mL}$ ) (vectors of mosquitoes). The synthesized AgNPs demonstrated acute toxicity at low dosages against the various larvae of mosquitoes [305]. Overall, their study results emphasized that AgNPs synthesized from B. cristata are promising and ecofriendly agents that can be used against the vectors of mosquito. In addition, Gomathi et al. [306] reported that AgNPs synthesized from the leaf extracts of B. cristata exhibited potent antimicrobial activity. The nanoparticles demonstrated extremely promising antibacterial activity against $E$. coli and $S$. aureus that were inhibited considerably [306]. These studies have shown that the phytochemical compounds present in leaf extracts could serve as reducing and capping agents of silver nitrate $\left(\mathrm{AgNO}_{3}\right)$, a frequently used precursor in AgNP synthesis. Medicinal plants are considered as a promising biological route for the synthesis of biocompatible metal nanoparticles. There is a scarcity of scientific information on the synthesis of AgNPs from plants extracts of species within Barleria. Therefore, it is necessary to screen more plant extracts for the biosynthesis of AgNPs as these particles have promising use in the nanotechnology industry and can be used as an affordable, environmentally friendly alternative to conventional medicine. 
Table 13. Biological activity of synthesized nanoparticles from extracts of species of Barleria.

\begin{tabular}{|c|c|c|c|c|c|c|}
\hline Plant Species & Plant Part & Extract & $\begin{array}{l}\text { Nanoparticles } \\
\text { Synthesised }\end{array}$ & $\begin{array}{l}\text { Reported Activity/Phytochemicals } \\
\text { Present }\end{array}$ & $\begin{array}{l}\text { Agent } \\
\text { Dosage }\end{array}$ & Reference \\
\hline \multirow[b]{2}{*}{ B. cristata } & \multirow[b]{2}{*}{ Leaves } & \multirow[b]{2}{*}{ Water } & $\mathrm{Ag} *$ & Mosquitocidal potential & $300 \mu \mathrm{g} / \mathrm{mL}$ & [305] \\
\hline & & & $\mathrm{Ag}$ & $\begin{array}{l}\text { Antibacterial activity against E. coli } \\
\text { and S. aureus }\end{array}$ & - & [306] \\
\hline B. longiflora & Leaves & Water & $\mathrm{Ag}$ & $\begin{array}{l}\text { Antimicrobial activity, inhibition of } \\
\text { Enterococcus sp., Streptococcus sp., } \\
\text { B. megaterium, P. putida, P. aeruginosa } \\
\text { and S. aureus and potential } \\
\text { application in photocatalytic dye } \\
\text { degradation processes }\end{array}$ & $10 \mu \mathrm{g} / \mathrm{mL}$ & [307] \\
\hline B. prionitis & Leaves & Water & $\mathrm{Ag}$ & $\begin{array}{l}\text { Polyphenols, starch, reducing sugars, } \\
\text { ascorbic acid and citric acid using } \\
\text { GC-MS analysis }\end{array}$ & - & [308] \\
\hline
\end{tabular}

* Silver.

\section{Advantages and Challenges}

To our knowledge, this review represents the first detailed report summarizing the phytochemical analysis of species belonging to the genus Barleria and correlating the pharmacological effects with its most important compounds. Information from this review combines reported literature on various species within Barleria, thus providing baseline information on the potential usage of the extracts. This review may offer as a model for studies trying to scientifically explain medicinal plants effects. Traditionally, the genus Barleria has significant medicinal potential; however, there is a scarcity of information on the clinical and food applications on species within the genus and a lack of scientific information on the biological activities of several species. The safety efficacy of several plants are not documented and need to be further validated. These are all aspects which deserve further validation.

\section{Conclusions}

This review describes a comprehensive account of the phytochemical constituents and biological activities of plants belonging to the genus Barleria. Several bioactive compounds isolated from Barleria species, such as iridoids, phenolics, flavonoids, terpenoids, phytosterols and phenylethanoid glycosides possess various biological properties of medicinal importance. Moreover, both extracts and bioactive compounds from Barleria have demonstrated several biological activities, including antioxidant, antibacterial, antifungal, anti-inflammatory, anticancer, antidiabetic, antiulcer, hepatoprotective, analgesic, antiamoebic, antihelmintic, antiarthritic, antihypertensive, antiviral, and acetylcholinesterase activity inhibition properties and the ability to synthesize silver nanoparticles. Further investigations are recommended to explore more about the species within Barleria to identify new therapeutic compounds or drug leads, as most of them have not yet been subjected to chemical and biological assessment. Therefore, further research on the bioactive compounds and pharmacological activities of plants within this genus will provide a basic understanding of the importance of these species as medicinal plants and a potential source of novel and useful drugs.

Author Contributions: Conceptualization, methodology, S.G. and Y.N.; investigation and data curation, S.G., Y.N. and Y.H.D.; writing-original draft preparation, S.G. and Y.N.; writing-review and editing, Y.H.D. and S.E.-H.; supervision, Y.N. and Y.H.D. All authors have read and agreed to the published version of the manuscript.

Funding: Authors extend their appreciation to the Deanship of Scientific Research at King Saud University for funding this work through research group NO (RGP-1438-012). 
Institutional Review Board Statement: Not applicable.

Informed Consent Statement: Not applicable.

Data Availability Statement: Not applicable.

Acknowledgments: Authors extend their appreciation to the Deanship of Scientific Research at King Saud University for funding this work through research group NO (RGP-1438-012). Authors acknowledge the National Research Foundation, South Africa.

Conflicts of Interest: The authors declare no conflict of interest.

\section{References}

1. Mayeng, I. Relationship between the sources of traditional and western medicine. In Indigenous Knowledge and Its Uses in Southern Africa; Normann, H., Synman, I., Cohen, M., Eds.; The Human Sciences Research Council Publishers: Pretoria, South Africa, 1996; pp. $45-50$.

2. Balandrin, M.; Kinghorn, A.; Farnsworth, N. Plant-derived natural products in drug discovery and development: An overview. ACS Symp. Ser. 1993. [CrossRef]

3. Jackson, M. A Global History of Medicine; Oxford University Press: Oxford, UK, 2018.

4. Walsh, J.J. Medieval Medicine, 1st ed.; BoD-Books on Demand: Norderstedt, Germany, 2018.

5. Kerdel-Vegas, F. Medical Paradoxes: Contradictions in Modern Medicine; Troubador Publishing Ltd.: Kibworth, UK, 2019.

6. Cowan, M.M. Plant products as antimicrobial agents. Clin. Microbiol. Rev. 1999, 12, 564-582. [CrossRef]

7. Lewis, K.; Ausubel, F.M. Prospects for plant derived antibacterials. Nat. Biotechnol. 2006, 24, 1504-1507. [CrossRef] [PubMed]

8. Rai, M.; Agarkar, G.; Rathod, D. Multiple applications of endophytic Colletotrichum species occurring in medicinal plants. In Novel Plant Bioresources: Applications in Food, Medicine and Cosmetics; Gurib-Fakin, A., Ed.; Wiley: Chichester, UK, 2014 ; pp. $227-236$. [CrossRef]

9. Umashankar, D.D. Plant secondary metabolites as potential usage in regenerative medicine. J. Phytopharmacol. 2020, 9, 270-273. [CrossRef]

10. Rabe, T.; Van Staden, J. Antibacterial activity of South African plants used for medicinal purposes. J. Ethnopharmacol. 1997, 56, 81-87. [CrossRef]

11. Buwa, L.V.; Van Staden, J. Antibacterial and antifungal activity of traditional medicinal plants used against venereal diseases in South Africa. J. Ethnopharmacol. 2006, 103, 139-142. [CrossRef]

12. Singh, A.; Mishra, A.; Chaudhary, R.; Kumar, V. Role of herbal plants in prevention and treatment of parasitic diseases. J. Sci. Res. 2020, 64, 50-58. [CrossRef]

13. Van Wyk, B.E.; Wink, M. Medicinal Plants Of the World; Briza Publications: Pretoria, South Africa, $2004 ;$ p. 480.

14. Hoareau, L.; Edgar, D.J. Medicinal plants: Are-emerging health aid. Plant Biotechnol. 1999, 2, 57-70. [CrossRef]

15. Shaila, M.; Begum, N. Ancient farming methods of seed storage and pest management practices in India-A Review. Plant Arch. 2021, 21, 499-509.

16. Vickers, A.; Zollman, C.; Lee, R. Herbal medicine. West. J. Med. 2001, 175, 125-128. [CrossRef]

17. Vlieghe, P.; Lisowski, V.; Martinez, J.; Khrestchatisky, M. Synthetic therapeutic peptides: Science and market. Drug Discov. 2010, 15, 40-56. [CrossRef] [PubMed]

18. Wood, M. The Book of Herbal Wisdom: Using Plants as Medicines; North Atlantic Books: Berkeley, CA, USA, 2017.

19. Sparg, S.G.; Van Staden, J.; Jäger, A.K. Pharmacological and phytochemical screening of two Hyacinthaceae species: Scilla natalensis and Ledebouria ovatifolia. J. Ethnopharmacol. 2002, 80, 95-101. [CrossRef]

20. Gamaniel, K.S.; Jsselmuiden, C.I. Ethical challenges posed by herbal traditional medicines research. In Proceedings of the 8th Global Forum for Health Research, Mexico City, Mexico, 16-20 November 2004.

21. Muhammad, B.Y.; Awaisu, A. The need for enhancement of research, development, and commercialization of natural medicinal products in Nigeria: Lessons from the Malaysian experience. Afr. J. Tradit. Complement. Altern. Med. 2008, 5, 120-130.

22. Balunas, M.J.; Kinghorn, A.D. Drug discovery from medicinal plants. Life Sci. 2005, 78, 431-441. [CrossRef]

23. Rates, S.M.K. Plants as source of drugs. Toxicon 2001, 39, 603-613. [CrossRef]

24. Newman, D.J.; Cragg, G.M.; Snader, K.M. Natural products as sources of new drugs over the period 1981-2002. J. Nat. Prod. 2003, 66, 1022-1037. [CrossRef] [PubMed]

25. Fabricant, D.S.; Farnsworth, N.R. The value of plants used in traditional medicine for drug discovery. Environ. Health Perspect. 2001, 109, 69-75. [CrossRef]

26. Cragg, C.M.; Newman, D.J.; Snader, M. Natural products in drug discovery and development. J. Nat. Prod. 1997, 60, 52-60. [CrossRef]

27. Vidhya, R.; Udayakumar, R. Gas chromatography-Mass spectrometry (GC-MS) analysis of ethanolic extracts of Aerva lanata (L.). Int. J. Biochem. Res. 2015, 7, 192-203. [CrossRef]

28. Khan, I.; Jan, S.A.; Shinwari, Z.K.; Ali, M.; Khan, Y.; Kumar, T. Ethnobotany and medicinal uses of folklore medicinal plants belonging to family Acanthaceae: An updated review. J. Biol. Med. 2017, 1, 34-38. 
29. Fongod, A.G.N.; Modjenpa, N.B.; Veranso, M.C. Ethnobotany of Acanthaceae in the Mount Cameroon region. J. Med. Plant Res. 2013, 7, 2859-2866. [CrossRef]

30. Koekemoer, M.; Steyn, H.M.; Bester, S.P. Guide to Plant Families of Southern Africa, Strelitzia 31; South African National Biodiversity Institute: Pretoria, South Africa, 2014.

31. Kar, A.; Pandit, S.; Mukherjee, K.; Bahadur, S.; Mukherjee, P.K. Safety assessment of selected medicinal food plants used in Ayurveda through CYP450 enzyme inhibition study. J. Sci. Food Agric. 2017, 97, 333-340. [CrossRef]

32. Makholela, T.; Van der Bank, H.; Balkwill, K. A preliminary study of allozyme variation in three rare and restricted endemic Barleria greenii (Acanthaceae) populations. Biochem. Syst. Ecol. 2003, 31, 141-154. [CrossRef]

33. Balkwill, M.J.; Balkwill, K. A preliminary analysis of distribution patterns in a large, pantropical genus, Barleria L. (Acanthaceae). J. Biogeogr. 1998, 25, 95-110. [CrossRef]

34. Pooley, E. A Field Guide to Wild Flowers KwaZulu-Natal and the Eastern Region, 1st ed.; Natal Flora Publication Trust: Durban, South Africa, 2005.

35. Grant, W.F. A cytogenetic study in the Acanthaceae. Brittonia 1955, 8, 121-149. [CrossRef]

36. Balkwill, M.J.; Balkwill, K. Delimitation and infra-generic classification of Barleria (Acanthaceae). Kew Bull. 1997, 52, 535-573. [CrossRef]

37. Kumar, H.; Agrawal, R.; Kumar, V. Barleria cristata: Perspective towards phytopharmacological aspects. J. Pharm. Pharmacol. 2018, 70, 475-487. [CrossRef] [PubMed]

38. Darbyshire, I.; Tripp, E.A.; Chase, F.M. A taxonomic revision of Acanthaceae tribe Barlerieae in Angola and Namibia. Part 1. Kew Bull. 2019, 74, 1-85. [CrossRef]

39. Mabberley, D.J. Mabberley's Plant-Book: A Portable Dictionary of Plants, their Classification and Uses, 3rd ed.; Cambridge University Press: Cambridge, UK, 2008.

40. Darbyshire, I. Barleria . In Flora of Tropical East Africa. Acanthaceae (Part 2); Beentje, H.J., Ed.; Royal Botanic Gardens: Kew, UK, 2010; pp. 325-442.

41. Darbyshire, I.; Vollesen, K.; Ensermu, K. Acanthaceae, part 2. In Flora Zambesiaca; Timberlake, J.R., Martins, E.S., Eds.; Royal Botanic Gardens: Richmond, UK, 2015; p. 304.

42. Kumari, R.; Kumar, S.; Kumar, A.; Goel, K.K.; Dubey, R.C. Antibacterial, antioxidant and immuno-modulatory properties in extracts of Barleria lupulina Lindl. BMC Complement. Altern. Med. 2017, 17, 1-11. [CrossRef] [PubMed]

43. Al-Hakimi, A.S.; Faridah, Q.Z.; Abdulwahab, A.S.; Latiff, A. Pollen and seed morphology of Barleria L.(Barlerieae: Ruellioideae: Acanthaceae) of Yemen. S. Afr. J. Bot. 2018, 116, 185-191. [CrossRef]

44. Singh, Y.; Baijnath, H.; Condy, G. Barleria elegans. In Flowering Plants of Africa; Grobler, A., Condy, G., Eds.; South African National Biodiversity Institute: Pretoria, South Africa, 2015; pp. 136-142.

45. Champluvier, D. New and overlooked Acanthaceae taxa from D.R. Congo, Rwanda and Burundi: (1) the genus Barleria. Plant Ecol. Evol. 2011, 144, 82-95. [CrossRef]

46. Hughes, M.; Moller, M.; Edwards, T.J.; Bellstedt, D.U.; De Villiers, M. The impact of pollination syndrome and habitat on gene flow: A comparative study of two Streptocarpus (Gesneriaceae) species. Am. J. Bot. 2007, 94, 1688-1695. [CrossRef]

47. Bremekamp, C.E.B. On the opening mechanism of the Acanthaceous fruit. S. Afr. J. Sci. 1926, 23, $488-491$.

48. Martínez-Berdeja, A.; Ezcurra, E.; Torres, M. Morphological variability in propagules of a desert annual as a function of rainfall patterns at different temporal and spatial scales. Funct. Ecol. 2015, 29, 1260-1267. [CrossRef]

49. Obermeijer, A.A. A revision of the South African species of Barleria. Ann. Transvaal Mus. 1933, 15, 123-180.

50. Bhogaonkar, P.Y.; Lande, S.K. Anatomical Characterization of Barleria prionitis Linn.: A well-known medicinal herb. Biol. Forum Int. J. 2012, 4, 1-5.

51. Tripp, E.A.; Fekadu, M. Comparative leaf and stem anatomy in selected species of Ruellieae (Acanthaceae) representative of all major lineages. Kew Bull. 2014, 69, 1-8. [CrossRef]

52. Kumar, V.; Singh, S. Gastroprotective activity of methanol leaves extract of Barleria prionitis Linn. on ethanol and indomethacin induced ulcer in rats. Br. J. Pharm. Res. 2013, 3, 817-829. [CrossRef]

53. Tamboli, F.A.; More, H.N. Evaluation of antiulcer and antioxidant activity of Barleria gibsoni Dalz. leaves. Pharmacogn. Res. 2016, 8, 226-230. [CrossRef]

54. Banerjee, S.; Banerjee, S.; Jha, G.K.; Bose, S. Barleria prionitis L.: An illustrative traditional, phytochemical and pharmacological: A review. J. Nat. Prod. 2021, 11, 258-274. [CrossRef]

55. Banerjee, S.; Banerjee, S.; Jha, G.K.; Bose, S. Conspectus of phytoconstituents and pharmacological activities of Barleria lupulina Lindl.: A Review. Curr. Tradit. Med. 2021, 7, 325-334. [CrossRef]

56. Sudheer, W.N.; Praveen, N. Phytochemical, pharmacological and tissue culture studies of some important species of the genus Barleria L. (Acanthaceae)—A review. Plant Sci. Today 2021, 8, 491-500. [CrossRef]

57. Jain, C.; Khatana, S.; Vijayvergia, R. Bioactivity of secondary metabolites of various plants: A review. Int. J. Pharm. Sci. Res. 2019, 10, 494-498. [CrossRef]

58. Yosook, C.; Panpisutchai, Y.; Chaichana, S.; Santisuk, T.; Reutrakul, V. Evaluation of anti-HSV-2 activities of Barleria lupulina and Clinacanthus nutans. J. Ethnopharmacol. 1999, 67, 179-187. [CrossRef] 
59. Wang, B.U.; Wu, M.; Perchellet, E.M.; Mcilvain, C.J.; Sperfslage, B.J.; Huang, X.; Tamura, M.; Stephany, H.A.; Hua, D.H.; Perchellet, J.P. Asynthetic triptycene bisquinone which blocks nucleoside transport and induces DNA fragmentation, retains its cytotoxic efficacy in daunorubicin-resistant HL-60 cell lines. Int. J. Oncol. 2001, 19, 1169-1178. [CrossRef] [PubMed]

60. Jassim, S.A.A.; Naji, A.M. Novel antiviral agents: A medicinal plant perspective. J. Appl. Microbiol. 2003, 95, 412-427. [CrossRef] [PubMed]

61. Suba, V.; Murugesan, T.; Arunachalam, G.; Mandal, S.C.; Saha, B.P. Anti-diabetic potential of Barleria lupulina extract in rats. Phytomedicine 2004, 11, 202-205. [CrossRef] [PubMed]

62. Suba, V.; Murugesan, T.; Pal, M.; Mandal, S.C.; Saha, B.P. Antiulcer activity of methanol fraction of Barleria lupulina Lindl. in animal models. Phytother. Res. 2004, 18, 925-929. [CrossRef] [PubMed]

63. Suba, V.; Murugesan, T.; Kumaravelrajan, R.; Mandal, S.C.; Saha, B.P. Antiinflammatory, analgesic and antiperoxidative efficacy of Barleria lupulina Lindl. extract. Phytother. Res. 2005, 19, 695-699. [CrossRef]

64. Chomnawang, M.T.; Surassmo, S.; Nukoolkarn, V.S.; Gritsanapan, W. Antimicrobial effects of Thai medicinal plants against acne-inducing bacteria. J. Ethnopharmacol. 2005, 101, 330-333. [CrossRef]

65. Shukla, S.; Gunjegaokar, S.M. Pharmacognostical and pharmacological profiling of Barleria prionitis Linn. J. Biol. Sci. Med. 2018, 4, $41-50$.

66. Amoo, S.O.; Finnie, J.F.; Van Staden, J. In vitro pharmacological evaluation of three Barleria species. J. Ethnopharmacol. 2009, 121, 274-277. [CrossRef] [PubMed]

67. Ata, A.; Kalhari, K.S.; Samarasekara, R. Chemical constituents of Barleria prionitis and their enzyme inhibitory and free radical scavenging activities. Phytochem. Lett. 2009, 2, 37-40. [CrossRef]

68. Jeyasankar, A.; Chinnamani, T. Effect of fractions of Barleria buxifolia and their biological activity against economically important lepidopteron pests. Int. J. Nat. Sci. 2017, 5, 43-49.

69. Chetan, C.; Suraj, M.; Maheshwari, C.; Rahul, A.; Priyanka, P. Screening of antioxidant activity and phenolic content of whole plant of Barleria prionitis Linn. Int. J. Res. Ayurveda Pharm. 2011, 2, 1313-1319.

70. Chowdhury, N.; Al-Hasan, A.; Tareq, F.S.; Ahsan, M.; Azam, A.Z. 4-Hydroxy-trans-cinnamate derivatives and triterpene from Barleria cristata. Dhaka Univ. J. Pharm. Sci. 2014, 12, 143-145. [CrossRef]

71. Jäger, A.K.; Hutchings, A.; Van Staden, J. Screening of Zulu medicinal plants for prostaglandin-synthesis inhibitors. J. Ethnopharmacol. 1996, 52, 95-100. [CrossRef]

72. Karim, A.; Noor, A.T.; Malik, A.; Qadir, M.I.; Choudhary, M.I. Barlerisides A and B, new potent superoxide scavenging phenolic glycosides from Barleria acanthoides. J. Enzym. Inhib. Med. Chem. 2009, 24, 1332-1335. [CrossRef] [PubMed]

73. Karim, A.; Noor, A.T.; Malik, A. Structure of barlericin, the neolignan diglycoside from Barleria acanthoides. J. Asian Nat. Prod. Res. 2010, 12, 714-718. [CrossRef]

74. Salib, J.Y.; Nabila, H.S.; Helana, N.M.; Emad, F.E. Antibacterial activity of Barleria cristata bark extracts. J. Appl. Sci. Res. 2013, 9, 2156-2159.

75. Hemalatha, K.; Hareeka, N.; Sunitha, D. Chemical constituents isolated from leaves of Barleria cristata Linn. Int. J. Pharma Bio Sci. 2012, 3, 609-615.

76. Ei-Mawla, A.; Ahmed, A.S.; Ibraheim, Z.Z.; Ernst, L. Phenylethanoid glycosides from Barleria cristata L. callus cultures. Bull. Pharm. Sci. Assiut Univ. 2005, 28, 199-204. [CrossRef]

77. Gololo, S.S.; Bassey, K.; Olivier, M.T.; Agyei, N.M.; Shai, L.J.; Masoko, P.; Gamedze, M.; Mogale, M.A. Isolation of an Iridoid glycoside compound from the leaves of Barleria dinteri collected from Zebediela sub-region in Limpopo province, South Africa. $J$. Pharm. Sci. 2017, 9, 1368.

78. Damtoft, S.; Jensen, S.R.; Nielsen, B.J. Structural revision of barlerin and acetyl barlerin. Tetrahedron Lett. 1982, 23, 4155-4156. [CrossRef]

79. Byrne, L.T.; Sasse, J.M.; Skelton, B.W.; Suksamrarn, A.P.I.C.H.A.R.T.; White, A.H. The minor iridoid glucosides of Barleria lupulina: Isolation, crystal structure and plant growth-inhibiting properties of 6-O-acetylshanzhiside methyl ester. Aust. J. Chem. 1987, 40, 785-794. [CrossRef]

80. Tuntiwachwuttikul, P.; Pancharoen, O.; Taylor, W.C. Iridoid glucosides of Barleria lupulina. Phytochemistry 1998, 49, 163-166. [CrossRef]

81. Kanchanapoom, T.; Kasai, R.; Yamasaki, K. Iridoid glucosides from Barleria lupulina. Phytochemistry 2001, 58, 337-341. [CrossRef]

82. Lans, C.; Harper, T.; Georges, K.; Bridgewater, E. Medicinal and ethnoveterinary remedies of hunters in Trinidad. BMC Complement. Altern. Med. 2001, 1, 1-17. [CrossRef]

83. Suksamrarn, S.; Wongkrajang, K.; Kirtikara, K.; Suksamrarn, A. Iridoid glucosides from the flowers of Barleria lupulina. Planta Med. 2003, 69, 877-879. [CrossRef] [PubMed]

84. Widyowati, R.; Tezuka, Y.; Miyahara, T.; Awale, S.; Kadota, S. Alkaline phosphatase (ALP) enhancing iridoid glucosides from the Indonesian medicinal plant Barleria lupulina. Nat. Prod. Commun. 2010, 5, 1934578X1000501101. [CrossRef]

85. Yadav, S.A.; Ramalingam, S.; Jebamalairaj, A.; Subban, R.; Sundaram, K.M. Biochemical fingerprint and pharmacological applications of Barleria noctiflora Lf leaves. J. Complement. Integr. Med. 2016, 13, 365-376. [CrossRef]

86. Kosmulalage, K.S.; Zahid, S.; Udenigwe, C.C.; Akhtar, S.; Ata, A.; Samarasekera, R. Glutathione S-transferase, acetylcholinesterase inhibitory and antibacterial activities of chemical constituents of Barleria prionitis. Z. Naturforsch. B. 2007, 62, 580-586. [CrossRef] 
87. Chen, J.L.; Blanc, P.; Stoddart, C.A.; Bogan, M.; Rozhon, E.J.; Parkinson, N.; Ye, Z.; Cooper, R.; Balick, M.; Nanakorn, W.; et al. New iridoids from the medicinal plant Barleria prionitis with potent activity against respiratory syncytial virus. J. Nat. Prod. 1998, 61, 1295-1297. [CrossRef] [PubMed]

88. Singh, K.A.M.I.N.I.; Gupta, R.S. Antifertility activity of $\beta$-sitosterol isolated from Barleria prionitis (L.) roots in male albino rats. Int. J. Pharm. Pharm. Sci. 2016, 8, 88-96.

89. Mabry, T.; Markham, K.R.; Thomas, M.B. The Systematic Identification of Flavonoids; Springer Science \& Business Media: Heidelberg, Germany, 1970; p. 55. [CrossRef]

90. Taneja, S.C.; Tiwari, H.P. Structure of two new iridoids from B. prionitis. Tetrahedron Lett. 1975, 24, 1995-1998. [CrossRef]

91. Daniel, M. Medicinal Plants: Chemistry and Properties; Science Publishers: Hauppauge, NY, USA, 2006.

92. Gupta, H.M.; Saxena, V.K. A new acylated luteolin-7-O- $\beta$-Dglucoside from the roots of Barleria prionitis (Linn.). Natl. Acad. Sci. Lett. 1984, 7, 187-189.

93. Daniel, M.; Sabnis, S.D. Chemosystematics of some Indian members of the Acanthaceae. Proc. Plant Sci. 1987, 97, 315-323. [CrossRef]

94. Kanchanapoom, T.; Noiarsa, P.; Ruchirawat, S.; Kasai, R.; Otsuka, H. Phenylethanoid and iridoid glycosides from the Thai medicinal plant, Barleria strigosa. Chem. Pharm. Bull. 2004, 52, 612-614. [CrossRef]

95. Harraz, F.M.; El-Halawany, A.M.; El Gayed, S.H.; Abdel-Sattar, E. Iridoid glycosides from Barleria trispinosa. Nat. Prod. Res. 2009, 23, 903-908. [CrossRef]

96. Didna, B.; Debnath, S.; Harigaya, Y. Naturally occurring iridoids. A review, Part 1. Chem. Pharm. Bull. 2007, 55, 159-222. [CrossRef]

97. Tundis, R.; Loizzo, M.R.; Menichini, F.; Statti, G.A.; Menichini, F. Biological and pharmacological activities of iridoids: Recent developments. Mini Rev. Med. Chem. 2008, 8, 399-420. [CrossRef] [PubMed]

98. Amoo, S.O.; Ndhlala, A.R.; Finnie, J.F.; Van Staden, J. Antifungal, acetylcholinesterase inhibition, antioxidant and phytochemical properties of three Barleria species. S. Afr. J. Bot. 2011, 77, 435-445. [CrossRef]

99. Salim, V.; Yu, F.; Altarejos, J.; De Luca, V. Virus-induced gene silencing identifies Catharanthus roseus 7-deoxyloganic acid-7hydroxylase, a step in iridoid and monoterpene indole alkaloid biosynthesis. Plant J. 2013, 76, 754-765. [CrossRef] [PubMed]

100. Marcucci, M.C.; Ferreres, F.; Garcla-Viguera, C.; Bankova, V.S.; De Castro, S.L.; Dantas, A.P.; Valente, P.H.M.; Paulino, N. Phenolic compounds from Brazilian propolis with pharmacological activities. J. Ethnopharmacol. 2001, 74, 105-112. [CrossRef]

101. Polya, G. Biochemical Targets of Plant Bioactive Compounds: A Pharmacological Reference Guide to Sites of Action and Biological Effects; CRC Press: Boca Raton, FL, USA, 2003. [CrossRef]

102. Hosseinimehr, S.J.; Pourmorad, F.; Shahabimajd, N.; Shahrbrandy, K.; Hosseinzadeh, R. In vitro antioxidant activity of Polygonium hyranicum, Centaurea depressa, Sambusus ebulus, Mentha spicata and Phytolacca americana. Pak. J. Biol. Sci. 2007, 10, 637-640. [CrossRef]

103. Saibabu, V.; Fatima, Z.; Khan, L.A.; Hameed, S. Therapeutic potential of dietary phenolic acids. Adv. Pharmacol. Sci. 2015, 2015, 1-10. [CrossRef] [PubMed]

104. Mandal, S.M.; Chakraborty, D.; Dey, S. Phenolic acids act as signaling molecules in plant-microbe symbioses. Plant Signal. Behav. 2010, 5, 359-368. [CrossRef] [PubMed]

105. Halliwell, B. Antioxidants in human health and disease. Annu. Rev. Nutr. 1996, 16, 33-50. [CrossRef]

106. Bernini, R.; Gualandi, G.; Crestini, C.; Barontini, M.; Bel, M.C.; Ore, S.; Willför, P.; Eklund, P.; Saladino, R. A novel and efficient synthesis of highly oxidized lignans by a methyltrioxorhenium/hydrogen peroxide catalytic system. Studies on their apoptogenic and antioxidant activity. Bioorg. Med. Chem. 2009, 17, 5676-5682. [CrossRef] [PubMed]

107. Teponno, R.B.; Kusari, S.; Spiteller, M. Recent advances in research on lignans and neolignans. Nat. Prod. Rep. 2016, 33, 1044-1092. [CrossRef]

108. Larson, R.A. The antioxidants of higher plants. Phytochemistry 1988, 27, 969-978. [CrossRef]

109. Jucá, M.M.; Filho, F.M.S.C.; De Almeida, J.C.; Mesquita, D.D.S.; Barrig'a, J.R.D.M.; Dias, K.C.F.; Barbosa, T.M.; Vasconcelos, L.C.; Leal, L.K.A.M.; Ribeiro, J.E.; et al. Flavonoids: Biological activities and therapeutic potential. Nat. Prod. Res. 2020, 34, 692-705. [CrossRef] [PubMed]

110. Burda, S.; Oleszek, W. Antioxidant and antiradical activities of flavonoids. J. Agric. Food Chem. 2001, 49, 2774-2779. [CrossRef]

111. Havsteen, B.H. The biochemistry and medical significance of the flavonoids. Pharmacol. Ther. 2002, 96, 67-202. [CrossRef]

112. Tunalier, Z.; Kosar, M.; Küpeli, E.; Çalis, I.; Baser, K.H.C. Antioxidant, anti-inflammatory, anti-nociceptive activities and composition of Lythrum salicaria L. extracts. J. Ethnopharmacol. 2007, 110, 539-547. [CrossRef] [PubMed]

113. Pattanayak, S.P.; Sunita, P. Wound healing, anti-microbial and antioxidant potential of Dendrophthoe falcata (L.f) Ettingsh. J. Ethnopharmacol. 2008, 120, 241-247. [CrossRef]

114. Wu, P.; Ma, G.; Li, N.; Deng, Q.; Yin, Y.; Huang, R. Investigation of in vitro and in vivo antioxidant activities of flavonoids rich extract from the berries of Rhodomyrtus tomentosa (Ait.) Hassk. Food Chem. 2015, 173, 194-202. [CrossRef]

115. Aust, O.; Sies, H.; Stahl, W.; Polidori, M.C. Analysis of lipophilic antioxidants in human serum and tissues: Tocopherols and carotenoids. J. Chromatogr. A 2001, 936, 83-93. [CrossRef]

116. Cushnie, T.; Lamb, A.J. Antimicrobial activity of flavonoids. Int. J. Antimicrob. Agents. 2005, 26, 343-356. [CrossRef]

117. Zwenger, S.; Basu, C. Plant terpenoids: Applications and future potentials. Biotechnol. Mol. Biol. 2008, 3, 001-007.

118. Prakash, V. Terpenoids as cytotoxic compounds: A perspective. Pharmacogn. Rev. 2018, 12, 166-176. [CrossRef] 
119. Yu, F.; Utsumi, R. Diversity, regulation, and genetic manipulation of plant mono-and sesquiterpenoid biosynthesis. Cell. Mol. Life Sci. 2009, 66, 3043-3052. [CrossRef] [PubMed]

120. Dudareva, N.; Klempien, A.; Muhlemann, J.K.; Kaplan, I. Biosynthesis, function and metabolic engineering of plant volatile organic compounds. New Phytol. 2013, 198, 16-32. [CrossRef] [PubMed]

121. Thoppil, R.J.; Bishayee, A. Terpenoids as potential chemopreventive and therapeutic agents in liver cancer. World J. Hepatol. 2011, 3, 228-249. [CrossRef] [PubMed]

122. Moreau, R.A.; Nyström, L.; Whitaker, B.D.; Winkler-Moser, J.K.; Baer, D.J.; Gebauer, S.K.; Hicks, K.B. Phytosterols and their derivatives: Structural diversity, distribution, metabolism, analysis, and health-promoting uses. Prog. Lipid Res. 2018, 70 , 35-61. [CrossRef] [PubMed]

123. Zhang, X.; Lin, K.; Li, Y. Highlights to phytosterols accumulation and equilibrium in plants: Biosynthetic pathway and feedback regulation. Plant Physiol. Biochem. 2020, 155, 637-649. [CrossRef] [PubMed]

124. dos Santos, M.A.Z.; Roehrs, M.; de Pereira, C.M.P.; Freitag, R.A.; de Bairros, A.V. Analysis of phytosterols in plants and derived products by gas chromatography-A short critical review. Austin Chromatogr. 2014, 1, 01-04.

125. Lee, S.R.; Clardy, J.; Senger, D.R.; Cao, S.; Kim, K.H. Iridoid and phenylethanoid glycosides from the aerial part of Barleria lupulina. Rev. Bras. De Farmacogn. 2016, 26, 281-284. [CrossRef]

126. Sena Filho, J.G.; Nimmo, S.L.; Xavier, H.S.; Barbosa-Filho, J.M.; Cichewicz, R.H. Phenylethanoid and lignan glycosides from polar extracts of Lantana, a genus of verbenaceous plants widely used in traditional herbal therapies. J. Nat. Prod. 2009, 72, $1344-1347$. [CrossRef]

127. Jensen, S.R. Systematic implications of the distribution of iridoids and other chemical compounds in the Loganiaceae and other families of the Asteridae. Ann. Mo. Bot. Gard. 1992, 284-302. [CrossRef]

128. Jimenez, C.; Riguera, R. Phenylethanoid glycosides in plants: Structure and biological activity. Nat. Prod. Rep. 1994, 11, 591-606. [CrossRef]

129. Xue, Z.; Yang, B. Phenylethanoid glycosides: Research advances in their phytochemistry, pharmacological activity and pharmacokinetics. Molecules 2016, 21, 991. [CrossRef] [PubMed]

130. Yildirim, A.; Oktay, M.; Bulaloulu, V. The antioxidant activity of the leaves of Cydonia vulgaris. Turk. J. Med. Sci. 2001, 31, 23-27.

131. Ames, B.N.; Shigenaga, M.K.; Hagen, T.M. Oxidants, antioxidants, and the degenerative diseases of aging. Proc. Natl. Acad. Sci. USA 1993, 90, 7915-7922. [CrossRef]

132. McCord, J.M. The evolution of free radicals and oxidative stress. Am. J. Med. 2000, 108, 652-659. [CrossRef]

133. Sa'nchez-Moreno, C.; Larrauri, J.A.; Saura-Calixto, F. A procedure to measure the antiradical efficiency of polyphenols. J. Sci. Food Agric. 1998, 76, 270-276. [CrossRef]

134. Hyldgaard, M.; Mygind, T.; Meyer, R.L. Essential oils in food preservation: Mode of action, synergies, and interactions with food matrix components. Front. Microbial. 2012, 3, 1-24. [CrossRef]

135. Jacob, R.A. The integrated antioxidant system. Nutr. Res. 1995, 15, 755-766. [CrossRef]

136. Willcox, J.K.; Ash, S.L.; Catignani, G.L. Antioxidants and prevention of chronic disease. Crit. Rev. Food Sci. Nutr. 2004, 44, 275-295. [CrossRef] [PubMed]

137. Stepien, P.; Klobus, G. Antioxidant defense in the leaves of C3 and C4 plants under salinity stress. Physiol. Plant. 2005, 125, 31-40. [CrossRef]

138. Choi, C.W.; Kim, S.C.; Hwang, S.S.; Choi, B.K.; Ahn, H.J.; Lee, M.Y.; Park, S.H.; Kim, S.K. Antioxidant activity and free radical scavenging capacity between Korean medicinal plants and flavonoids by assay-guided comparison. Plant Sci. 2002, 163, 1161-1168. [CrossRef]

139. McCall, M.R.; Frei, B. Can antioxidant vitamins materially reduce oxidative damage in humans? Free Radic. Biol. Med. 1999, 26, 1034-1053. [CrossRef]

140. Jaiswal, S.K.; Dubey, M.K.; Das, S.; Verma, A.R.; Rao, C.V. A comparative study on total phenolic content, reducing power and free radical scavenging activity of aerial parts of Barleria prionitis. Int. J. Phytomedicine 2010, 2. [CrossRef]

141. Ramchoun, M.; Harnafi, H.; Alem, C.; Benlys, M.; Elrhaffari, L.; Amrani, S. Study on antioxidant and hypolipidemic effects of polyphenol rich extract from Thymus vulgaris and Lavendula multifida. Pharmacogn. Res. 2009, 1, 106-112.

142. Amoo, S.O.; Van Staden, J. Pharmacological properties and in vitro shoot production of Barleria argillicola-A critically endangered South African species. S. Afr. J. Bot. 2013, 85, 87-93. [CrossRef]

143. Sujatha, A.P.; Doss, A.; Muthukumarasamy, S.; Mohan, V.R. Study of antioxidant activity of Barleria courtrallica. Res. J. Life Sci. Bioinform. Pharm. Chem. Sci. 2018, 4, 513-521.

144. Amutha, K.; Doss, D.V.A. Identification and antimicrobial activity of saponin fraction from the leaves of Barleria cristata L. Int. J. Pharm. Sci. Res. 2012, 3, 4040-4044.

145. Narmadha, R.; Devaki, K. In vitro antioxidant activity and in vitro aglucosidase and a-amylase inhibitory activity of Barleria Cristata L. Res. J. Pharm. Biol. Chem. Sci. 2012, 3, 780-788.

146. Pathy, M.; Sharma, T.; Bhatnagar, S. Barleria cristata: A comparative analysis of phytochemical, cytotoxic and antioxidant activities of leaf and bark extracts. Eur. J. Pharm. Med. Res. 2015, 5, 586-593.

147. Vasanth, S.; Bupesh, G.; Vijayakumar, T.S.; Balachandar, V.; Gunasekaran, D.R. Evaluation of in vitro antidiabetic and antioxidant potential of Barleria cristata leaves extracts. Asian J. Pharm. Clin. Res. 2018, 11, 287-290. [CrossRef] 
148. Gololo, S.S.; Mogale, M.A.; Agyei, N.M.; Shai, L.J. Phytochemical, antioxidant and antibacterial screening of the leaves of Barleria dinteri (Oberm), Grewia flava (DC) and Jatropha lagarinthoides (Sond). J. Chem. Pharm. Res. 2016, 8, 56-60.

149. Sawarkar, H.A.; Khadabadi, S.S.; Wandhare, M.D.; Farooqui, I.A.; Deokate, U.A. The antioxidant activity of the leaves of Barleria grandiflora dalz.(acanthaceae). Ethnobot. Leaflets. 2009, 13, 443-449.

150. Sriram, S.; Sasikumar, C.G. Therapeutic Effect of Barleria montana Wight \& Nees Leaf Extract Inflammation and Ulcer in Albino Wistar Rats. Ph.D. Thesis, Bharathidasan Universit, Tamil Nadu, India, 2017.

151. Banu, S.; Arunachalam, G.; Jayaveera, K.N.; Ashoka Babu, V.L.; Premakumari, K.B. Estimation of total phenolic content and in vitro antioxidant activity of Barleria Montana. Der Pharm. Lett. 2011, 3, 178.

152. Mathew, J.; Arora, K.M.; Mazumdar, A.; Kumar, G.; Karthik, L.; Rao, K.V.B. Evaluation of phytochemical composition and antioxidant activity of aqueous extract of Barleria mysorensis and Furcraea foetida leaves. Res. J. Pharm. Technol. 2012, 5, 1503-1508.

153. Yadav, S.A.; Raj, A.J.; Sathishkumar, R. In vitro antioxidant activity of Barleria noctiflora L. f. Asian Pac. J. Trop. Biomed. 2012, 2, S716-S722. [CrossRef]

154. Manjula, M.S.; Ganthi, A.S. In-vitro antioxidant and anti-inflammatory potential of ethanol extracts (root and aerial parts) of Barleria noctiflora. Ann. Plant Sci. 2018, 7, 1997-2001. [CrossRef]

155. Arumugam, S.; Natesan, S.; Ganesan, S.; Kanagarajan, S. In vitro screening of various extract of Barleria noctiflora for their antioxidant and free radical scavenging activity. Int. J. Pharm. Phytopharmacol. Res. 2015, 5, 41-49.

156. Kapoor, A.; Shukla, S.; Kaur, R.; Kumar, R.; Lehra, K.S.; Kapoor, S. Preliminary Phytochemical Screening and antioxidant activity of whole plant of Barleria prionitis linn. Int. J. Adv. Pharm. Biol. Chem. 2014, 3, 410-419.

157. Ranade, R.; Jain, A.; Joshi, N. Estimation of phenolic compounds by RP-HPLC and antioxidant activity in leaf and stem extracts of Barleria prionitis L. Int. J. Pharm. Sci. Res. 2016, 7, 2445.

158. Sharma, P.; Sharma, G.N.; Shrivastava, B.; Jadhav, H.R. Evaluation of antioxidant potential of Barleria prionitis leaf and stem. Am. J. Phytomed. Clin. Ther. 2014, 2, 177-186.

159. Kumar, U.; Ahmed, F.; Khanojia, P.; Kukreja, K.; Kumari, S.; Bhat, R.A. Exploration of antioxidant and antibacterial activity of Barleria prionitis linn. Int. J. Curr. Microbiol. Appl. Sci. 2013, 2, 585-591.

160. Sawarkar, H.A.; Kashyap, P.P.; Kaur, C.D. RBC Haemolysis prevention and antioxidant activity of Barleria prionitis. Chiang Mai J. Sci. 2018, 45, 888-896.

161. Shukla, R. Study of phytochemical investigation and in vitro antioxidant potential of hydroalcoholic extract of Barleria prionitis. Int. J. Pharm. Sci. Drug Res. 2019, 7, 73-78.

162. Deepak, M.; Sulaiman, C.; Balachandran, I.; Chandran, K.P.S. Identification of medicinally active flavonoids, phenolic compounds and terpenoids from traditional healing plant Barleria strigosa and its antioxidant activity. Asian J. Green Chem. 2021, 5, 12-22.

163. Prapalert, W.; Santiarworn, D.; Liawruangrath, S.; Liawruangrath, B.; Pyne, S.G. Two phenylethanoid glycosides, Parvifloroside A and B, isolated from Barleria strigosa. Chiang Mai J. Sci. 2017, 44, 168-175.

164. Van Vuuren, S.; Muhlarhi, T. Do South African medicinal plants used traditionally to treat infections respond differently to resistant microbial strains? S. Afr. J. Bot. 2017, 112, 186-192. [CrossRef]

165. Elbashiti, T.A.; Elmanama, A.A.; Masad, A.A. The antibacterial and synergistic effects of some Palestinian plant extracts on Escherichia coli and Staphylococcus aureus. Funct. Plant Biol. 2011, 5, 57-62.

166. Ncube, B.; Finnie, J.; Van Staden, J. In vitro antimicrobial synergism within plant extract combinations from three South African medicinal bulbs. J. Ethnopharmacol. 2012, 139, 81-89. [CrossRef]

167. Islam, R.; Rahman, M.S.; Rahman, S.M. GC-MS analysis and antibacterial activity of Cuscuta reflexa against bacterial pathogens. Asian Pac. J. Trop. Dis. 2015, 5, 399-403. [CrossRef]

168. Srivastava, P.; Upreti, D.K.; Dhole, T.N.; Srivastava, A.K.; Nayak, M.T. Antimicrobial property of extracts of Indian lichen against human pathogenic bacteria. Interdiscip. Perspect. Infect. Dis. 2013, 2013, 1-6. [CrossRef] [PubMed]

169. Aneja, K.R.; Joshi, R.; Sharma, C. Potency of Barleria prionitis L. bark extracts against oral diseases causing strains of bacteria and fungi of clinical origin. N. Y. Acad. Sci. 2010, 3, 5-12.

170. Bency, A.; Lohidas, J.; Murugan, M. Phytochemical studies and antibacterial activity of Barleria acuminata Nees (Acanthaceae). J. Pharmacogn. Phytochem. 2018, 7, 1909-1911.

171. Sulthana, B.S.; Honey, E.; Anasuya, B.; Gangarayudu, H.; Reddy, M.J.; Girish, C. Investigation of anti-bacterial activity of different extracts of Barleria cristata leaves. Int. J. Health Sci. 2017, 7, 90-95.

172. Myint, S.; Moe, Z.M.; Khaing, M.M. Morphological characters of Barleria cristata L. and Barleria prionitis L. and their antimicrobial activities. J. Myanmar. Acad. Arts. Sci. 2020, 18, 183-191.

173. Sawarkar, H.A.; Kashyap, P.P.; Pandey, A.K.; Singh, M.K.; Kaur, C.D. Antimicrobial and cytotoxic activities of Barleria prionitis and Barleria grandiflora: A comparative study. Bangladesh J. Pharmacol. 2016, 11, 802-809. [CrossRef]

174. Kumari, R.; Dubey, R.C. Phytochemical analysis and antibacterial and cytotoxic properties of Barleria lupulina Lindl. extracts. J. Plant Pathol. Microbiol. 2016, 7, 1-6. [CrossRef]

175. Moin, S.; Babu, S.S.; Mahalakshmipriya, A. In vitro callus production and antibacterial activity of Barleria lupulina lindl. Asia Pac. J. Mol. Biol. Biotechnol. 2012, 20, 59-64.

176. Sarmad, M.; Mahalakshmipriya, A.; Senthil, K. Chemical composition and in-vitro antimicrobial activity of Barleria lupulina essential oil. J. Herbs Spices Med. Plants. 2012, 18, 101-109. [CrossRef] 
177. Natarajan, D.; Gomathi, M.; Yuvarajan, R. Phytochemical and antibacterial evaluation of Barleria montana Nees. (MOUNTAIN Barleria). Asian J. Pharm. Clin. Res. 2012, 5, 44-46.

178. Tulliballi, S.; Seru, G. Phytochemical investigation and evaluation of hepatoprotective and antimicrobial activities on the aerial parts of Barleria montana (Acanthaceae). Rasayan J. Chem. 2013, 6, 102-106. [CrossRef]

179. Sridharan, S.; Chinnagounder, S. Evaluation of antimicrobial activity and GC-MS profiling of Barleria montana. J. Pharm. Res. 2012, 5, 2921-2925.

180. Gangopadhyaym, A.; Malakar, J.; Ghosh, A.; Pramanik, G.; Karmakar, S. Comparative antibacterial study of Barleria prionitis Linn. leaf extracts. Int. J. Pharm. Biol. Arch. 2012, 3, 391-393.

181. Diwan, P.D.; Gadhikar, Y.A. Assessment of phytochemical composition and antibacterial activity of different extracts of Barleria prionitis leaves against oral microflora to improve dental hygiene. Asian J. Pharm. Clin. Res. 2012, 5, 182-184.

182. Amit, K.; Shiwani, S.; Rajesh, K.; Rajinder, K.; Singh, L.K.; Shilpa, K. Pharmacognostical, preliminary phytochemical screening and antimicrobial studies of leaves of Barleria prionitis Linn. Int. J. Pharmacogn. Phytochem. Res. 2014, 6, 369-378.

183. Patel, B.K.; Chandel, B.S.; Chauhan, H.C.; Patel, K.B.; Parth, F.M.; Patel, M.V.; Patel, S.I.; Pandya, R.P.; Shah, J.D. Evaluation of antibacterial activities of Barleria Prionitis Linn. Afr. J. Microbiol. Res. 2015, 9, 1840-1848. [CrossRef]

184. Kumari, P.; Yadav, P.; Arya, A.; Kumar, S. In vitro callus production and anti-bacterial activity of Barleria prionitis linn. against dental caries pathogens. Int. J. Bot. Res. 2013, 3, 1-6.

185. Chavan, C.B.; Shinde, U.V.; Hogade, M.; Bhinge, S. Screening of in-vitro antibacterial assay of Barleria proinitis LINN. J. Herb. Med. Toxicol. 2010, 4, 197-200.

186. Manapradit, N.; Poeaim, S.; Charoenying, P. Cytotoxicity and antimicrobial activities of leaf extracts from Barleria strigosa. Int. J. Agric. Technol. 2015, 11, 551-561.

187. Jankowska, M.; Lemańska, M.; Trocha, H.; Gesing, M.; Smiatacz, T. Opportunistic infections in HIV-positive patients hospitalized in the Clinic of Infectious Diseases AMG. Przegl. Epidemiol. 2001, 55, 125-128.

188. Awasthi, K.; Das, A.; Prasad, T. Detection of Multidrug-Resistant Fungal Infections in Cancer Patients. In Molecular Markers in Mycology; Singh, B., Gupta, V., Eds.; Springer: Cham, Switzerland, 2017; pp. 335-352. [CrossRef]

189. Denning, D.W. Minimizing fungal disease deaths will allow the UNAIDS target of reducing annual AIDS deaths below 500000 by 2020 to be realized. Philos. Trans. Biol. Sci. 2016, 371, 1-10. [CrossRef]

190. Hamza, O.J.; van den Bout-van, C.J.; Matee, M.I.; Moshi, M.J.; Mikx, F.H.; Selemani, H.O.; Mbwambo, Z.H.; Van der Ven, A.J.; Verweij, P.E. Antifungal activity of some Tanzanian plants used traditionally for the treatment of fungal infections. $J$. Ethnopharmacol. 2006, 108, 124-132. [CrossRef]

191. Doddanna, S.J.; Patel, S.; Sundarrao, M.A.; Veerabhadrappa, R.S. Antimicrobial activity of plant extracts on Candida albicans: An in vitro study. Indian J. Dent. Res. 2013, 24, 401-405. [CrossRef]

192. Chellathai, D. Evaluation of antibacterial and antifungal activity of Barleria cristata-An in vitro study. World. J. Pharm. Res. 2015, $2,1253-1258$.

193. Kumari, S.; Jain, P.; Sharma, B.; Kadyan, P.; Dabur, R. In vitro antifungal activity and probable fungicidal mechanism of aqueous extract of Barleria grandiflora. Appl. Biochem. Biotechnol. 2015, 175, 3571-3584. [CrossRef] [PubMed]

194. Sawarkar, H.A.; Kashyap, P.P.; Kaur, C.D.; Pandey, A.K.; Biswas, D.K.; Singh, M.K.; Dhongade, H.K. Antimicrobial and TNF- $\alpha$ Inhibitory Activity of Barleria prionitis and Barleria grandiflora: A Comparative Study. Indian J. Pharm. Sci. 2016, 50, 409-417. [CrossRef]

195. Panchal, P.; Singh, K. Antimicrobial activity of Barleria prionitis on pathogenic strains. Int. J. Curr. Pharm. Res. $2015,7,73-75$.

196. Ghule, B.V.; Yeole, P.G. In vitro and in vivo immunomodulatory activities of iridoids fraction from Barleria prionitis Linn. J. Ethnopharmacol. 2012, 141, 424-431. [CrossRef] [PubMed]

197. Singh, A.; Pathak, V.M.; Navneet. Screening of antimicrobial potential of Barleria prionitis Linn aerial parts against common respiratory tract pathogens. Int. J. Curr. Microbiol. Appl. Sci. 2016, 5, 542-549. [CrossRef]

198. Iwalewa, E.O.; McGaw, L.J.; Naidoo, V.; Eloff, J.N. Inflammation: The foundation of diseases and disorders. A review of phytomedicines of South African origin used to treat pain and inflammatory conditions. Afr. J. Biotechnol. 2007, 6, 2868-2885. [CrossRef]

199. Fawole, O.A.; Amoo, S.O.; Ndhlala, A.R.; Light, M.E.; Finnie, J.F.; Van Staden, J. Anti-inflammatory, anticholinesterase, antioxidant and phytochemical properties of medicinal plants used for pain-related ailments in South Africa. J. Ethnopharmacol. 2010, 127, 235-241. [CrossRef]

200. Cos, P.; Vlietinck, A.J.; Berghe, D.V.; Maes, L. Anti-infective potential of natural products: How to develop a stronger in vitro 'proof-of-concept'. J. Ethnopharmacol. 2006, 106, 290-302. [CrossRef]

201. Zschocke, S.; Van Staden, J. Cryptocarya species—substitute plants for Ocotea bullata? A pharmacological investigation in terms of cyclooxygenase-1 and -2 inhibition. J. Ethnopharmacol. 2000, 71, 473-478. [CrossRef]

202. Singh, B.; Bani, S.; Gupta, D.K.; Chandan, B.K.; Kaul, A. Anti-inflammatory activity of 'TAF' an active fraction from the plant Barleria prionitis Linn. J. Ethnopharmacol. 2003, 85, 187-193. [CrossRef]

203. Gambhire, M.N.; Wankhede, S.S.; Juvekar, A.R. Antiinflammatory activity of aqueous extract of Barleria cristata leaves. J. Young Pharmacist . 2009, 1, 220-224. [CrossRef]

204. Gambhire, M.; Juvekar, M.; Juvekar, A.; Wankhede, S.; Sakat, S. Evaluation of anti-inflammatory and radical scavenging activity of an aqueous extract of Barleria cristata leaves. Planta Med. 2009, 75, PJ166. [CrossRef] 
205. Senger, D.R.; Hoang, M.V.; Kim, K.H.; Li, C.; Cao, S. Anti-inflammatory activity of Barleria lupulina: Identification of active compounds that activate the Nrf2 cell defense pathway, organize cortical actin, reduce stress fibers, and improve cell junctions in microvascular endothelial cells. J. Ethnopharmacol. 2016, 193, 397-407. [CrossRef] [PubMed]

206. Wanikiat, P.; Panthong, A.; Sujayanon, P.; Yoosook, C.; Rossi, A.G.; Reutrakul, V. The anti-inflammatory effects and the inhibition of neutrophil responsiveness by Barleria lupulina and Clinacanthus nutans extracts. J. Ethnopharmacol. 2008, 116, 234-244. [CrossRef] [PubMed]

207. Sridharan, S.; Venkatramani, M.; Janakiraman, K.; Pemiah, B. Barleria montana Wight and Nees- A promising natural antiinflammatory agent against formalin induced inflammation. Int. J. Pharm. Pharm. Sci. 2015, 7, 80-84.

208. Khadse, C.D.; Kakde, R.B. Anti-inflammatory activity of aqueous extract fractions of Barleria prionitis L. roots. Asian J. Plant Sci. Res. 2011, 1, 63-68.

209. Ghule, B.V.; Kotagale, N.R.; Patil, K.S. Inhibition of the pro-inflammatory mediators in rat neutrophils by shanzhiside methyl ester and its acetyl derivative isolated from Barleria prionitis. J. Ethnopharmacol. 2020, 249, 112374. [CrossRef]

210. Jemal, A.; Bray, F.; Center, M.M.; Ferlay, J.; Ward, E.; Forman, D. Global cancer statistics. CA Cancer J. Clin. 2011, 61, 69-90. [CrossRef] [PubMed]

211. El-Halawany, A.M.; Abdallah, H.M.; Hamed, A.R.; Khalil, H.E.; Almohammadi, A.M. Phenolics from Barleria cristata var. Alba as carcinogenesis blockers against menadione cytotoxicity through induction and protection of quinone reductase. BMC Complement. Altern. Med. 2018, 18, 1-7. [CrossRef]

212. Manglani, N.; Vaishnava, S.; Dhamodaran, P.; Sawarkar, H. In vitro and in vivo anticancer activity of leaf extract of Barleria grandiflora. Int. J. Pharm. Pharm. Res. 2014, 6, 70-72.

213. Tamboli, F.A.; More, H.N. Inhibitory Effects of successive solvent extracts of Barleria gibsoni Dalz. on the proliferation of MDA MB 4355 (Human Breast Cancer) and Hep G2 (Liver Cancer Cell line). Asian J. Pharm. Res. 2015, 5, 183-185. [CrossRef]

214. Kumari, R.; Kumar, S. Cytotoxicity and mitochondrial-mediated apoptosis induced by ethanolic leaf extract of Barleria lupulina Lindl. in human leukemia cells via reactive oxygen species generation. Preprints 2020, 2020050019. [CrossRef]

215. Panchal, P.; Meena, S.; Singh, K.; Sharma, N. Anticancer and antimicrobial potential of Barleria prionitis leaves ethanol extract. Int J. Pharm. Pharm. Sci. 2018, 10, 100. [CrossRef]

216. Akhtar, F.M.; Ali, M.R. Study of the anti-diabetic effect of a compound medicinal plant prescription in normal and diabetic rabbit. J. Pak. Med. Assoc. 1980, 34, 239-244.

217. Larner, J. Insulin and oral hypoglycemic drug, Glucogan. In The Pharmacological Basis of Therapeutics, 7th ed.; Gilman, A.G., Goodman, L.S., Rall, I.W., Murad, F., Eds.; Macmillan: New York, NY, USA, 1985; pp. 1490-1516.

218. Singh, R.; Rajasree, P.H.; Sankar, C. Screening for anti-diabetic activity of the ethanolic extract of Barleria cristata seeds. Int. J. Pharm. Biol. 2012, 3, 2044-2047.

219. Reema, D.; Pradeep, B. A study of the antidiabetic activity of Barleria prionitis Linn. Indian J. Pharmacol. 2010, 42, 70-73. [CrossRef]

220. Ezzat, S.M.; Abdel-Sattar, E.; Harraz, F.M.; Ghareib, S.A. Antihyperglycemic and antihyperlipidemic effects of the methanol extracts of Cleome ramosissima Parl., Barleria bispinosa (Forssk.) Vahl. and Tribulus macropterus Boiss. Bull. Fac. Pharm. Cairo Univ. 2014, 52, 1-7. [CrossRef]

221. Shyam, T.; Ganapaty, S. Evaluation of antidiabetic activity of methanolic extracts from the aerial parts of Barleria montana in streptozotocin induced diabetic rats. J. Pharmacogn. Phytochem. 2013, 2, 187-192.

222. Arumugam, S.; Natesan, S.K. Hypoglycemic effects of Barleria noctiflora fractions on high fat fed with low dose Streptozotocin induced type-2 diabetes in rats. Int. J. Pharm. Pharm. Sci. 2016, 8, 193-200.

223. Manjula, M.S.; Ganthi, A.S. In-vitro anti-diabetic activity of root and aerial parts of Barleria noctiflora Lf (Acanthaceae). Ann. Plant Sci. 2018, 7, 1073-1075.

224. Arumugam, S.; Natesan, S.K.; Ganesan, S.; Kanagarajan, S. Wound healing activity of ethyl acetate fraction of Barleria noctiflora in experimentally induced diabetic rats. J. Pharm. Res. 2016, 15, 6-9. [CrossRef]

225. Geetha, M.; Wahi, A.K. Antidiabetic activity of Barleria prionitis Linn. J. Nat. Remedies 2001, 1, $64-66$.

226. Alkofahi, A.; Atta, A.H. Pharmacological screening of the anti-ulcerogenic effects of some Jordanian medicinal plants in rats. J. Ethnopharmacol. 1999, 67, 341-345. [CrossRef]

227. Al-Snafi, A.E. Arabian medicinal plants possessed gastroprotective effects-plant based review (part 1). IOSR J. Pharm. 2018, 8 , 77-95.

228. Peskar, B.M.; Maricic, N.E.N.A.D. Role of prostaglandins in gastroprotection. Dig. Dis. Sci. 1998, 43, 23S-29S. [PubMed]

229. Khadeerunnisa, S.; Kumar, S.N.; Rajaram, C.; Manohar, R.; Reddy, K.R. Evaluation of antiulcer activity of methanolic extract of Barleria buxifolia in experimental rats. Res. J. Pharm. Technol. 2020, 13, 533-537. [CrossRef]

230. Jaiswal, S.K.; Dubey, M.K.; Das, S.; Rao, C.V. Gastroprotective effect of the iridoid fraction from Barleria prionitis leaves on experimentally-induced gastric ulceration. Chin. J. Nat. Med. 2014, 12, 738-744. [CrossRef]

231. Choudhary, M.; Kumar, V.; Singh, S. Gastro protective potential of chloroform leaves extract of Barleria prionitis Linn.: From traditional use to scientific approach. Adv. Chem. Biochem. Sci. 2014, 1, 1-11.

232. Lee, C.H.; Park, S.W.; Kim, Y.S.; Kang, S.S.; Kim, J.A.; Lee, S.H.; Lee, S.M. Protective mechanism of glycyrrhizin on acute liver injury induced by carbon tetrachloride in mice. Biol. Pharm. Bull. 2007, 30, 1898-1904. [CrossRef]

233. Chattopadhyay, R.R. Possible mechanism of hepatoprotective activity of Azadirachta indica leaf extract: Part II. J. Ethnopharmacol. 2003, 89, 217-219. [CrossRef] 
234. Jain, M.; Kapadia, R.; Jadeja, R.N.; Thounaojam, M.C.; Devkar, R.V.; Mishra, S.H. Protective role of standardized Feronia limonia stem bark methanolic extract against carbon tetrachloride induced hepatotoxicity. Ann. Hepatol. 2012, 11, 935-943. [CrossRef]

235. Recknagel, R.O. A new direction in the study of carbon tetrachloride hepatotoxicity. Life Sci. 1983, 33, 401-408. [CrossRef]

236. Wendel, A.; Feuerstein, S.; Konz, K.H. Acute paracetamol intoxication of starved mice leads to lipid peroxidation in vivo. Biochem. Pharmacol. 1979, 28, 2051-2055. [CrossRef]

237. Dianzani, M.U.; Muzia, G.; Biocca, M.E.; Canuto, R.A. Lipid peroxidation in fatty liver induced by caffeine in rats. Int. J. Tissue React. 1991, 13, 79-85. [PubMed]

238. Subramaniam, S.; Khan, H.B.H.; Elumalai, N.; Lakshmi, S.Y.S. Hepatoprotective effect of ethanolic extract of whole plant of Andrographis paniculata against $\mathrm{CCl}_{4}$-Induced hepatotoxicity in rats. Comp. Clin. Pathol. 2015, 24, 1245-1251. [CrossRef]

239. Balaji, P.; Kishore, G.; Verma, Y. In-vivo hepatoprotective activity of Barleria cristata L. ethanolic leaf extracts against $\mathrm{CCl}_{4}$ induced hepatic injury in wistar rats. Pharm. Glob. 2013, 4, 1-6.

240. Singh, B.; Chandan, B.K.; Prabhakar, A.; Taneja, S.C.; Singh, J.; Qazi, G.N. Chemistry and hepatoprotective activity of an active fraction from Barleria prionitis Linn. in experimental animals. Phytother. Res. 2005, 19, 391-404. [CrossRef] [PubMed]

241. Tabassum, S.S.; Rajaram, C.; Kumar, S.N.; Manohar, R.; Reddy, K.R. Evaluation of hepatoprotective activity of the methanolic extract of Barleria Cuspidata against $\mathrm{CCl}_{4}$ induced liver damage in experimental rats. Res. J. Pharm. Technol. 2020, 13, 538542. [CrossRef]

242. Lakshman Kumar, D.; Sravani, M.; Venkatesh, P.; Hepcy Kala Rani, D.; Purushothaman, M.; Sucharitha, P.A.M. Hepatoprotective activity of aqueous ethanolic extract of aerial parts of Barleria gibsoni on pct-induced hepatotoxicity in rats. World J. Pharm. Res. 2015, 4, 1973-1980.

243. Banu, S.; Arunachalam, G.; Jayaveera, K.N.; Babu, V.A.; Kumar, V. Hepatoprotective activity of methanolic extract of Barleria montana leaves in ethanol treated rats. Asian Pac. J. Trop. Dis. 2012, 2, S748-S752. [CrossRef]

244. Gilron, I.; Coderre, T.J. Emerging drugs in neuropathic pain. Expert Opin. Emerg. Drugs 2007, 1, 113-126. [CrossRef] [PubMed]

245. Manchikanti, L.; Boswell, M.V.; Hirsch, J.A. Lessons learned in the abuse of pain-relief medication: A focus on healthcare costs. Expert review of neurotherapeutics. Expert Rev. Neurother. 2013, 13, 527-544. [CrossRef] [PubMed]

246. Begum, A.; Venkatesh, S.; Bolleddu, R.; Alvala, R.; Jaya, D. Mechanistic evaluation of antinociceptive effects of bioactive guided fractions of Barleria prionitis. Int. J. Pharm. Sci. Nanotechnol. 2017, 10, 3715-3718. [CrossRef]

247. Martinez-Palomo, A. The pathogenesis of amoebiasis. Parasitol. Today 1987, 3, 111-118. [CrossRef]

248. Samie, A.; ElBakri, A.; AbuOdeh, R. Amoebiasis in the tropics: Epidemiology and Pathogenesis In Current Topics in Tropical Medicine; Rodríguez-Morales, A., Ed.; InTech: Rijeka, Croatia, 2012; pp. 201-226. [CrossRef]

249. Kapoor, K.; Chandra, M.; Nag, D.; Paliwal, J.K.; Gupta, R.C.; Saxena, R.C. Evaluation of metronidazole toxicity: A prospective study. Int. J. Clin. Pharmacol. Res. 1999, 19, 83-88.

250. Hanna, R.M.; Dahniya, M.H.; Badr, S.S.; El-Betagy, A. Percutaneous catheter drainage in drug-resistant amoebic liver abscess Trop. Med. Int. Health 2000, 5, 578-581. [CrossRef]

251. Upcroft, P.; Upcroft, J.A. Drug targets and mechanisms of resistance in the anaerobic protozoa. Clin. Microbiol. Rev. 2001, 14, 150-164. [CrossRef]

252. Bansal, D.; Sehgal, R.; Chawla, Y.; Mahajan, R.C.; Malla, N. In vitro activity of antiamoebic drugs against clinical isolates of Entamoeba histolytica and Entamoeba dispar. Ann. Clin. Microbiol. Antimicrob. 2004, 3, 27. [CrossRef] [PubMed]

253. Toumi, S.; Hammouda, M.; Essid, A.; Medimagh, L.; Slamia, L.B.; Laouani-Kechrid, C. Metronidazole-induced reversible cerebellar lesions and peripheral neuropathy. Med. Mal. Infect. 2009, 39, 906-908. [CrossRef]

254. Sawangjaroen, N.; Phongpaichit, S.; Subhadhirasakul, S.; Visutthi, M.; Srisuwan, N.; Thammapalerd, N. The anti-amoebic activity of some medicinal plants used by AIDS patients in southern Thailand. Parasitol. Res. 2006, 98, 588-592. [CrossRef]

255. Hotez, P.J.; Brindley, P.J.; Bethony, J.M.; King, C.H.; Pearce, E.J.; Jacobson, J. Helminth infections: The great neglected tropical diseases. J. Clin. Investig. 2008, 118, 1311-1321. [CrossRef]

256. Idika, I.K.; Okonkwo, E.A.; Onah, D.N.; Ezeh, I.O.; Iheagwam, C.N.; Nwosu, C.O. Efficacy of levamisole and ivermectin in the control of bovine parasitic gastroenteritis in the sub-humid savanna zone of southeastern Nigeria. Parasitol. Res. 2012, 111, 1683-1687. [CrossRef] [PubMed]

257. Tripathi, K.D. Essentials of Medical Pharmacology, 6th ed.; Jaypee Brothers Medical Publishers Ltd.: New Delhi, India, 2008.

258. Chander, P.A.; Sri, H.Y.; Sravanthi, N.B.; Susmitha, U.V. In vitro anthelmintic activity of Barleria buxifolia on Indian adult earthworms and estimation of total flavonoid content. Asian Pac. J. Trop. Dis. 2014, 4, 233-235. [CrossRef]

259. Chavan, C.B.; Hogade, M.G.; Bhinge, S.D.; Kumbhar, M.; Tamboli, A. In vitro anthelmintic activity of fruit extract of Barleria prionitis Linn. against Pheretima posthuma. Int. J. Pharm. Pharm. Sci. 2010, 2, 49-50.

260. Tamboli, F.A.; More, H.N. Anthelmintic activity of leaves extract of Barleria gibsoni Dalz. against Pheretima posthuma. J. Pharmacogn. Phytochem. 2016, 5, 250.

261. Kaur, R.; Kaur, G.; Goyal, S.; Kapoor, A.; Kaur, T. Preliminary phytochemical screening and in vitro anthelmintic activity of whole plant extracts of Barleria prionitis Linn. against earth worms: Pheretima posthuma. World J. Pharm. Pharm. Sci. 2015, 4, $1340-1347$.

262. Paval, J.; Kaitheri, S.K.; Potu, B.K.; Govindan, S.; Kumar, R.S.; Narayanan, S.N.; Moorkoth, S. Anti-arthritic potential of the plant Justicia gendarussa Burm F. Clinics 2009, 64, 357-362. [CrossRef] 
263. Banji, D.; Pinnapureddy, J.; Banji, O.J.F.; Kumar, A.R.; Reddy, K.N. Evaluation of the concomitant use of methotrexate and curcumin on Freund's complete adjuvant-induced arthritis and haematological indices in rats. Indian J. Pharmacol. 2011, 43, 546-550. [CrossRef]

264. Patil, M.V.K.; Kandhare, A.D.; Bhise, S.D. Anti-arthritic and anti-inflammatory activity of Xanthium srtumarium L. ethanolic extract in Freund's complete adjuvant induced arthritis. Biomed. Aging Pathol. 2012, 2, 6-15. [CrossRef]

265. Murugananthan, G.; Kumar, S.G.; Sathya, C.P.; Mohan, S. Antiarthritic and anti-inflammatory constituents from medicinal plants. J. Appl. Pharm. Sci. 2013, 3, 161-164.

266. Campbell, S.M. Rheumatoid arthritis: Current strategies. J. Hosp. Med. 1988, 34, $29-32$.

267. Nandi, P.; Kingsley, G.H.; Scott, D.L. Disease-modifying antirheumatic drugs other than methotrexate in rheumatoid arthritis and seronegative arthritis. Curr. Opin. Rheumatol. 2008, 20, 251-256. [CrossRef] [PubMed]

268. Choudhary, M.; Kumar, V.; Gupta, P.K.; Singh, S. Anti-arthritic activity of Barleria prionitis Linn. leaves in acute and chronic models in Sprague Dawley rats. Bull. Fac. Pharm. Cairo Univ. 2014, 52, 199-209. [CrossRef]

269. Mazumder, P.M.; Mondal, A.; Sasmal, D.; Arulmozhi, S.; Rathinavelusamy, P. Evaluation of antiarthritic and immunomodulatory activity of Barleria lupulina. Asian Pac. J. Trop. Biomed. 2012, 2, 1400-1406. [CrossRef]

270. Basini, J.; Sathrapalli, S. November. In Vivo anti-arthritic activity of ethanolic extract of Barleria montana Nees leaves against chemical induced arthritis. In Conference on Drug Design and Discovery Technologies; Royal Society of Chemistry: London, UK, 2019; Volume 355, p. 143. [CrossRef]

271. Sivakumar, G.; Sivakumar, G.A. Evaluation of Anti-arthritic activity of Methanolic extract of Barleria prionitis on CFA induced rats. Asian J. Pharm. Technol. 2019, 9, 159-164. [CrossRef]

272. WHO. Global Atlas on Cardiovascular Disease Prevention and Control. World Health Organization in Collaboration with the World Heart Federation and the World Stroke Organization; WHO Press: Geneva, Switzerland, 2013.

273. Singh, P.; Mishra, A.; Singh, P. Hypertension and herbal plant for its treatment: A review. Indian J. Res. Pharm. Biotechnol. 2015, 3 , 2320-3471.

274. Marya, B.H.; Bothara, S.B. Investigation of antihypertensive activity of leaves of Barleria prionitis in doca salt induced hypertensive rats. Int. J. Pharm. Sci. Rev. Res. 2013, 18, 17-19.

275. Drexler, M. What You Need to Know About Infectious Disease; The National Academies Press: Washington, DC, USA, 2010.

276. Neiderud, C.J. How urbanization affects the epidemiology of emerging infectious diseases. Infect. Ecol. Epidemiol. 2015, 5, 27060. [CrossRef] [PubMed]

277. Irwin, K.K.; Renzette, N.; Kowalik, T.F.; Jensen, J.D. Antiviral drug resistance as an adaptive process. Virus Evol. 2016, 2, 1-10. [CrossRef]

278. Rosini, M.; Andrisano, V.; Bartolini, M.; Bolognesi, M.L.; Hrelia, P.; Minarini, A.; Tarozzi, A.; Melchiorre, C. Rational approach to discover multipotent anti-Alzheimer drugs. J. Med. Chem. 2005, 48, 360-363. [CrossRef]

279. Khan, A.S. Flowering Plants: Structure and Industrial Products; John Wiley \& Sons: Hoboken, NJ, USA, 2017. [CrossRef]

280. Ahmad, W.; Ahmad, B.; Ahmad, M.; Iqbal, Z.; Nisar, M.; Ahmad, M. In vitro inhibition of acetylcholinesterase, butyrylcholinesterase and lipoxygenase by crude extract of Myricaria elegans Proc. R. Soc. Biol. Sci. 2003, 11, 1046-1049. [CrossRef]

281. Ferreira, A.; Proença, C.; Serralheiro, M.L.M.; Araújo, M.E.M. The in vitro screening for acetylcholinesterase inhibition and antioxidant activity of medicinal plants from Portugal. J. Ethnopharmacol. 2006, 108, 31-37. [CrossRef] [PubMed]

282. Narmadha, R.; Devaki, K. Toxicological evaluation and oral glucose tolerance test of ethanolic leaf extract of Barleria cristata L. in wistar albino rats. Int. J. Basic Clin. Pharmacol. 2013, 2, 742-746. [CrossRef]

283. Albrecht, M.A.; Evans, C.W.; Raston, C.L. Green chemistry and the health implications of nanoparticles. Green Chem. 2006, 8 , 417-432. [CrossRef]

284. Mittal, J.; Batra, A.; Singh, A.; Sharma, M.M. Phytofabrication of nanoparticles through plants as nanofactories. Adv. Nat. Sci. Nanosci. Nanotechnol. 2014, 5, 1-10. [CrossRef]

285. Sigamoney, M.; Shaik, S.; Govender, P.; Krishna, S.B.N. African leafy vegetables as bio-factories for silver nanoparticles: A case study on Amaranthus dubius C Mart. Ex Thell. S. Afr. J. Bot. 2016, 103, 230-240. [CrossRef]

286. Devi, S.R.; Selvan, S.A.C. Greener synthesis and characterization of silver nanoparticles using Murraya koenigii leaf extract and its antibacterial activity. Int. J. Pharma Bio Sci. 2017, 8, 292-298. [CrossRef]

287. Khatoon, N.; Mazumder, J.A.; Sardar, M. Biotechnological applications of green synthesized silver nanoparticles. J Nanosci. Curr. Res. 2017, 2, 1-8. [CrossRef]

288. Iravani, S. Green synthesis of metal nanoparticles using plants. Green Chem. 2011, 13, 2638-2650. [CrossRef]

289. Safavi, K. Evaluation of using nanomaterial in tissue culture media and biological activity. In Proceedings of the 2nd International Conference on Ecological, Environmental and Biological, Sciences, Bali, Indonesia, 13-14 October 2012.

290. Vanaja, M.; Annadurai, G. Coleus aromaticus leaf extract mediated synthesis of silver nanoparticles and its bactericidal activity. Appl. Nanosci. 2012, 9, 1-7. [CrossRef]

291. Liao, H.; Nehl, C.L.; Hafner, J.H. Biomedical applications of plasmon resonant metal nanoparticles. Future Med. $2006,1,201-208$. [CrossRef] [PubMed]

292. Rai, M.; Yadav, A.; Gade, A. Silver nanoparticles as a new generation of antimicrobials. Biotechnol. Adv. 2009, 27, 76-83. [CrossRef]

293. Kim, J.S.; Kuk, E.; Yu, K.N.; Kim, J.H.; Park, S.J.; Lee, H.J.; Cho, M.H. Antimicrobial effects of silver nanoparticles. Nanomedicine 2007, 3, 95-101. [CrossRef] 
294. Huh, A.J.; Kwon, Y.J. Nanoantibiotics: A new paradigm for treating infectious diseases using nanomaterials in the antibiotic resistant era. J. Control. Release 2011, 156, 128-145. [CrossRef]

295. Sousa, C.; Botelho, C.; Oliveira, R. Nanotechnology applied to medical biofilms control. In Science against Microbial Pathogens: Communicating Current Research and Technological Advances; Formatex Research Center: Badajoz, Spain, 2011.

296. Bhatt, P.; Tandel, K.; Sheter, V.; Rathi, K.R. Burden of extensively drug-resistant and pandrug-resistant gram-negative bacteria at a tertiary-care centre. New Microbes New Infect. 2015, 8, 166-170. [CrossRef]

297. Morones, J.R.; Elechiguerra, J.L.; Camacho, A.C.; Holt, K.; Kouri, J.B.; Ramirez, J.T.; Yacaman, M.J. The bactericidal effect of silver nanoparticles. Nanotechnology 2005, 16, 2346-2353. [CrossRef]

298. Savithramma, N.; Rao, M.L.; Rukmini, K.; Devi, P.S. Antimicrobial activity of silver nanoparticles synthesized by using medicinal plants. Int. J. ChemTech Res. 2011, 3, 1394-1402.

299. Lee, H.J.; Lee, G.; Jang, N.R.; Yun, J.H.; Song, J.Y.; Kim, B.S. Biological synthesis of copper nanoparticles using plant extract. Nanotechnology 2011, 1, 371-374.

300. Khalil, A.T.; Ovais, M.; Ullah, I.; Ali, M.; Shinwari, Z.K.; Hassan, D.; Maaza, M. Sageretia thea (Osbeck.) modulated biosynthesis of $\mathrm{NiO}$ nanoparticles and their in vitro pharmacognostic, antioxidant and cytotoxic potential. Artif. Cells Nanomed. Biotechnol. 2018, 46, 838-852. [CrossRef]

301. Chinnasamy, C.; Tamilselvan, P.; Karthik, V.; Karthik, B. Optimization and characterization studies on green synthesis of silver nanoparticles using response surface methodology. Adv. Nat. Appl. Sci. 2017, 11, 214-221.

302. Maddila, S.; Hemalatha, K.P.J. Phytochemical screening and in vitro antimicrobial properties of crude leaf extracts of Wrightia tinctoria R.Br. Int. J. Curr. Microbiol. Appl. Sci. 2017, 6, 707-720. [CrossRef]

303. Salunke, G.R.; Ghosh, S.; Kumar, R.S.; Khade, S.; Vashisth, P.; Kale, T.; Chopade, S.; Pruthi, V.; Kundu, G.; Bellare, J.R.; et al. Rapid efficient synthesis and characterization of silver, gold, and bimetallic nanoparticles from the medicinal plant Plumbago zeylanica and their application in biofilm control. Int. J. Nanomed. 2014, 9, 2635-2653. [CrossRef]

304. Daima, H.K.; Kachhwaha, S.; Kothari, S.L. Synthesis of plant mediated silver nanoparticles using papaya fruit extract and evaluation of their antimicrobial activities. Dig. J. Nanomater. Biostructures 2009, 4, 723-727.

305. Govindarajan, M.; Benelli, G. Facile biosynthesis of silver nanoparticles using Barleria cristata: Mosquitocidal potential and biotoxicity on three non-target aquatic organisms. Parasitol. Res. 2016, 115, 925-935. [CrossRef] [PubMed]

306. Gomathi, M.; Rajkumar, P.V.; Prakasam, A. Study of dislocation density (defects such as Ag vacancies and interstitials) of silver nanoparticles, green-synthesized using Barleria cristata leaf extract and the impact of defects on the antibacterial activity. Results Phys. 2018, 10, 858-864. [CrossRef]

307. Cittrarasu, V.; Balasubramanian, B.; Kaliannan, D.; Park, S.; Maluventhan, V.; Kaul, T.; Liu, W.C.; Arumugam, M. Biological mediated Ag nanoparticles from Barleria longiflora for antimicrobial activity and photocatalytic degradation using methylene blue. Artif. Cells Nanomed. Biotechnol. 2019, 47, 2424-2430. [CrossRef]

308. Ghosh, S.; Chacko, M.J.; Harke, A.N.; Gurav, S.P.; Joshi, K.A.; Dhepe, A.; Kulkarni, A.S.; Shinde, V.S.; Parihar, V.S.; Asok, A.; et al. Barleria prionitis leaf mediated synthesis of silver and gold nanocatalysts. J. Nanomed. Nanotechnol. 2016, 7, 1-7. [CrossRef] 